BNL- -52316

\title{
LITERATURE REVIEW \\ OF UNITED STATES UTILITIES COMPUTER CODES FOR CALCULATING ACTINIDE ISOTOPE CONTENT IN IRRADIATED FUEL
}

\author{
William C. Horak and Ming-Shih Lu
}

December, 1991

DEPARTMENT OF NUCLEAR ENERGY

BROOKHAVEN NATIONAL LABORATORY. ASSOCIATED UNIVERSITIES, INC. UPTON, LONG ISLAND. NEW YORK 11973

PREPARED FOR THE UNITED STATES DEPARTMENT OF ENERGY 
DISCLAIMER

This report was prepared as an account of work sponsored by an agency of the United $S$ tates Government. Nefther the United $S$ tates Government nor any agency thereof, nor any of their employees, nor any of their contractors, subcontractors, or their employees makes any warranty, express or implied, or assumes any legal liablilty or responsibllity for the accuracy, completeness, or usefulness of any information, apparatus, product or process disclosed, or represents that 1 ts use would not infringe privately owned rights. Reference herein to any specific commercial product, process, or service by trade name, trademark, manufacturer, or otherwise, does not necessarily constitute or imply its endorsement, recommendation, or favoring by the United States Government or any agency thereof. The views and opinfons of authors expressed herein do not necessarily state or reflect those of the United States Government or any agency, contractor, or subcontractor thereof. 


\begin{abstract}
The accuracy and precision of methods used by electric utilities to determine the actinide isotopic and element content of irradiated fuel are reviewed. The available experimental data were also used to assess the accuracy of the calculational methods. Most of the actinide isotopic content were estimated to within $5 \%$ of benchmark values, with the exception of the isotopes $\mathrm{Pu}-238, \mathrm{Pu}-242$ and $\mathrm{Np}-237$. The large relative errors in $\mathrm{Pu}-238$ and $\mathrm{Pu}-242$ do not cause a large error in total Pu mass since their fractions in spent fuel are small.
\end{abstract}


This paper reviews the accuracy and precision of methods used by United States electric utilities to determine the actinide isotopic and element content of irradiated fuel. After an extensive literature search, three key code suites were selected for review. Two suites of computer codes, CASMO and ARMP, are used for reactor physics calculations; the ORIGEN code is used for spent fuel calculations. They are also the most widely used codes in the nuclear industry throughout the world. Although none of these codes calculate actinide isotopics as their primary variables intended for safeguards applications, accurate calculation of actinide isotopic content is necessary to fulfill their function.

These codes have been benchmarked against experimentally determined values for isotopic content of irradiated fuel and to various standard problems. The data base includes fuel rods from Vermont Yankee, Zion, H.B. Robinson, and the SAXTON nuclear plants. Comparisons have also been made to standard problems developed at the Brookhaven National Laboratory. The codes calculated the majority of the actinide isotopic content to within 5\% of the benchmark values, with the exception of the isotopes Pu-238, Pu-242, and Np-237. The large relative errors in Pu-238 and Pu-242 do not cause a large error in total $\mathrm{Pu}$ mass since their fractions are small in power reactor spent fuel. 
Page No.

$\begin{array}{ll}\text { Abstract } & \text { iii } \\ \text { Summary } & \mathbf{v} \\ \text { List of Figures } & \text { viii } \\ \text { List of Tables } & \text { ix }\end{array}$

1.0 Introduction 1

2.0 Summary Description of Computer Codes 6

2.1 CASMO-3G 6

2.2 ORIGEN2 7

2.3 ARMP/EPRI-CELL 8

3.0 Comparisons of Coće Predicted Isotopic Contents to Experiments 9

3.1. Light Water Reactor Experimental Data Base 9

3.2 Reactor Power History and Burnup 9

3.3 CASMO-3G Comparisons 9

3.4 ORIGEN Comparisons 18

3.5 EPRI-CELL Validation ? 24

4.0 Comparisons to BNL Standard Physics Pioblem 33

$\begin{array}{ll}5.0 \text { Conclusions } & 35\end{array}$

$\begin{array}{ll}\text { References } & 39\end{array}$ 
List of Figures

Page No.

Figure 1.1 Process Stream of Physics Codes 2

Figure 1.2 Prosess Stream of ARMP PWR Physics Codes 4

Figure 3.1 U-235 Atom Percent versus Burnup of Yankee Core I as 10 Calculated by the Casmo Code

Figure 3.2 U-236 Atom Percent versus Burnup for Yankee Core I as Calculated by the Casmo Code

Figure 3.3 U-238 Atom Percent versus Burnup for Yankee Core I as Calculated by the Casmo Code

Figure 3.4 Pu-239/U-238 Atom Ratio versus Burnup for Yankee Core I 13 as Calculated by the Casmo Code

Figure 3.5 Pu-239 Atom Percent versus Burnup for Yankee Core $\mathbb{I}$ as Calculated by the Casmo Code

Figure 3.6 Pu-240 Atom Percent versus Burnup for Yankee Core I as Calculated by the Casmo Code

Figure 3.7 Pu-241 Atom Percent versus Burnup for Yankee Core I as 16 Calculated by the Casmo Code

Figure 3.8 Pu-242 Atom Percent versus Burnup for Yankee Core I as 17 Calculated by the Casmo Code

Figure 3.9 Pu-239/Pu-240 Atom Ratio versus Accumulated Fissions for 29 Yankee Core I as Calculated by the EPRI-Cell Code

Figure 3.10 Plutonium Isotopic Ratios versus U-235 Fractional 30 Depletion for Yankee Core V Zircalloy Assemblies as Calculated by the EPRI-Cell Code 
List of Tables

Page No.

Table 3.1 Zion Isotopics as Calculated by the CASMO Code 19

Table 3.2 Comparison of H.B. Robinson Fuel Composition Data 20 with ORIGEN Predictions

$\begin{array}{lll}\text { Table 3.3 ORIGEN Average Measured/Predicted Ratios } & 21\end{array}$

Table 3.4 Relative Agreement of ORIGEN Predictions for Various 22 Isotopes

Table 3.5 Comparison of Measured and ORIGEN Predicted Values " 23 for Irradiated H.B. Robinson Fuel

Table 3.6 Ratios of Predicted-to-Measured Values of Nuclides 25 in Fuel from ATM-103 and ATM-106

Table 3.7 Percentage Deviations of OREST Calculations from the Measured Values For Obrigheim Reactor

Table 3.8 Comparison Between Experiment and OREST Calculations for Obrigheim Reactor

Table 3.9 Comparison Between EPRI-CELL and SAXTON Experimental Data

Table 3.10 Compurison of Isotopic Ratios Calculated by EPRI-CELL 32 and experimental Data for H.B. Robinson

Table 4.1 Comparison Between CASMO and LEOPARD Results for Brookhaven National Laboratory

Table 5.1 Accuracy of Calculated Actinide Isotopic Contents 36

Table 5.2 Summary of ORIGEN Results for the Plutonium Isotopes 37 


\subsection{Introduction}

This paper reviews the accuracy and precision of methods used by United States electric utilities to determine the actinide isotopic and element content of irradiated fuel. The calculation of the actinide content of irradiated fuel requires the use of scphisticated computer codes. United States utilities have a wide variety of computer codes that do calculate actinide content. The codes used fall into two categories, depending on their primary function: 1) Reactor physics codes, whose primary purpose is to calculate neutronic parameters such as $k_{\text {eff }}$ and Doppler coefficients, reactor power distribution, and other parameters for safe operation required by the US NRC (United State Nuclear Regulatory Commission) approved technical specifications. Accurate reactor physics information is also necessary for the optimization of fuel management through the fuel cycle. 2) Spent fuel codes, whose primary goal is to calculate such characteristics of irradiated fuel as thermal load from decay heat and radiation fields for storage and transportation safety considerations. Although neither type has as its primary calculational parameter actinide content, they both require accurate calculation of the actinide content to fulfill their functions. Therefore, as part of their validation procedure, the code predicted actinide content of irradiated fuel has been compared to the actinide content of bundles determined experimentally, usually by chemical analysis of dissolved fuel samples. The standard test method, ASTM E321-79(1), uses the stable fission product Nd-148 to determine burnup in irradiated uranium fuels having an initial plutonium content ranging from 0 to $50 \%$.

Reactor physics codes are usually used to predict, before irradiation, the core neutronics parameters, local power distribution, average power level, and fuel burnup of a particular core fuel load over its expected lifetime of operation. The core neutronic parameters calculated include eigenvalues, Doppler worth, moderator worths, and control rod worths. Local power distributions and average power levels are important parameters in the technical specifications that govern the safe operation of the plant. Maximizing the fuel burnup is of extreme economic importance to the operating utility.

These parameters require an extremely accurate calculation of the neutron flux at many different spatial locations. The codes, therefore, usually perform multi-dimensional neutron physics calculations using many neutron energy groups. Sophisticated cross-section libraries ar required for these calculations. The cross-sections are highly energy dependent (frequently as many as 50 groups are used), and burnup dependent. Other important neutronic parameters, such as the resonance escape probability, are computed at each stage instead of a constant value being used.

These calculations usuaily require the use of a suite of codes, of which the depletion code, which calc' '? ates the isotopic content, is one part. Figure 1.1 shows the process stream for one such suite of codes, MICBURN-3/CASMO-3/TABLES-3/SIMULATE-3. ${ }^{(2)}$ In this case, the calculational stream is fairly straightforward, with the MICBURN-3 code performing calculations on fuel pins containing the burnable poison gadolinium. The 
Figure $1.1^{\circ}$

\section{Process Stream of Physics Codes}

'Reference 7

Code Names

Function

Provlde effectsve cross sictlons for

MICBURN-3

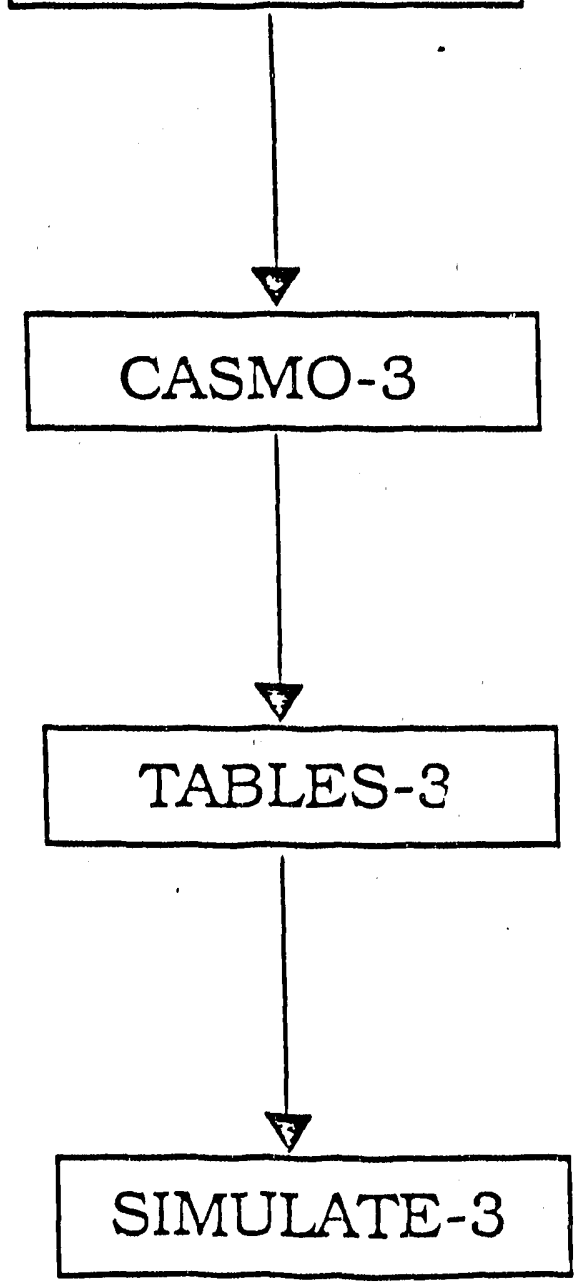

a pin as gadolindum burns out

Provide assembiy homogendzed two-group cross sections, kdnetics data and local peaking factors. Also, fux discontinuity data. reflector cross sections and gamma detector responses.

Process cross sections, etc. into functionalized tables

Provide 3-D power, vold, exposure and flssion product distributions for statlc reactor conditions. 
CASMO-3 code provides the remaining cross-sections and kinetics data necessary for the three-dimensional neutronics calculations done in SIMULATE-3. The depletion calculation is actually done in CASMO-3, although it is not shown on this chart.

However, the calculational stream is not so simple in many suites of reactor physics codes. The actual physical problem being solved is extremely complex, with much feedback between the modules. Figure 1.2 shows the calculational scheme for the EPRI (Electric Power Research Institute) suite of reactor physics codes, ARMP (Advanced Recycle Methodology Program) ${ }^{(3)}$. The ARMP suite of codes is one of the most widely used core neutronic packages in the United States and the world. As can be seen, there are many feedback loops in this arrangement, and the depletion calculations are done at several stages.

Spent fuel codes are usually run on a stand-alone basis, although they too can be part of a suite of codes. The key parameters in this calculation are usually thermal loads, photon emissions, and neutron emissions. After 3 cycles of residence in a reactor, most fuel assemblies experienced similar integrated exposure conditions. Thus, to determine the parameters of spent fuel safety, a detailed calculation of the neutron flux is not required. Because of this, the neutronics calculations are greatly simplified. Usually, the neutron flux is considered to be point-wise constant, i.e., there are no spatial changes in the flux. Since these codes are usually run after the fuel has been irradiated, and the power history and exposure known, in many cases the neutron flux is usually approximated in terms of the known average pewer history that the fuel was exposed to. The depletion calculation itself is greatly simplified, with the cross sections usually (with the exception of the actinides) not burnup dependent. ORIGEN $2^{(4)}$ is probably the most widely used of the spent fuel codes.

It was decided to limit the discussion of United States utilities methods to determine actinide isotopic content to a few key computer codes, rather than conduct a full assessment of all such codes. Such a wide ranging assessment would be beyond the resources allot'ed to this project. In researching the reactor physics methods used by U.S. utilities, literature searches were conducted of several information data bases. A large number of reactor physics codes used by utilities or vendors were identified. Many of these codes are proprietary in nature and their documentation, therefore, extremely limited. It was decided to limit the discussion of reactor physics codes to two prototypic and widely used suite of codes, the CASMO/MICBURN/SIMULATE package and the ARMP package. CASMO is typical of the codes designed to use so-called nodal methods, which came into wide use in the 1980s. EPRI-CELL, which does the pin depletion calculation in the ARMP package, was designed to be used with PDQ-7 ${ }^{(5)}$, a finite difference method-based code developed in the 1970s, that is still widely used. The literature searches of spent fuel codes were dominated by references to the ORIGEN family of codes. This code is the most widely used in the field. This was verified by private discussions with members of the Waste Management Division of the Department of Nuclear Energy of the Brookhaven National Laboratory'. 


\section{Process Stream of ARMP PWR Physics Codes}

'Reference 2

BOI CPM
for
Control
Element
Represen-
tation

-

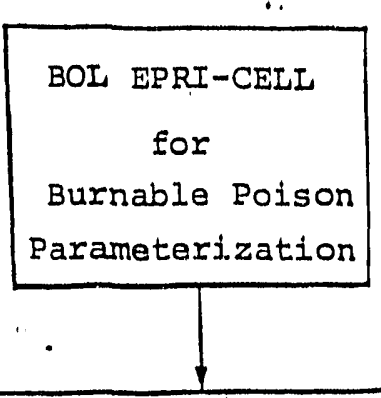

PDQ $-7 /$ HARMONY

\begin{tabular}{|c|c|c|}
\hline $\begin{array}{c}\text { Optional Core } X-Y \\
\text { Depletion }\end{array}$ & $\begin{array}{c}\text { Core } X-Y \\
\text { Beginning of Cycle (BOC) }\end{array}$ & $\begin{array}{c}\text { Assembly } X-Y \\
\text { Depletion }\end{array}$ \\
\hline
\end{tabular}

Core

Rearrangement for Next Cycle

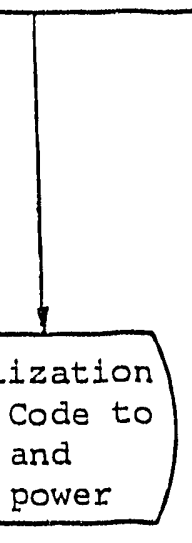

BOL Normalization of Global Code to PDQ $K$ and assembly power

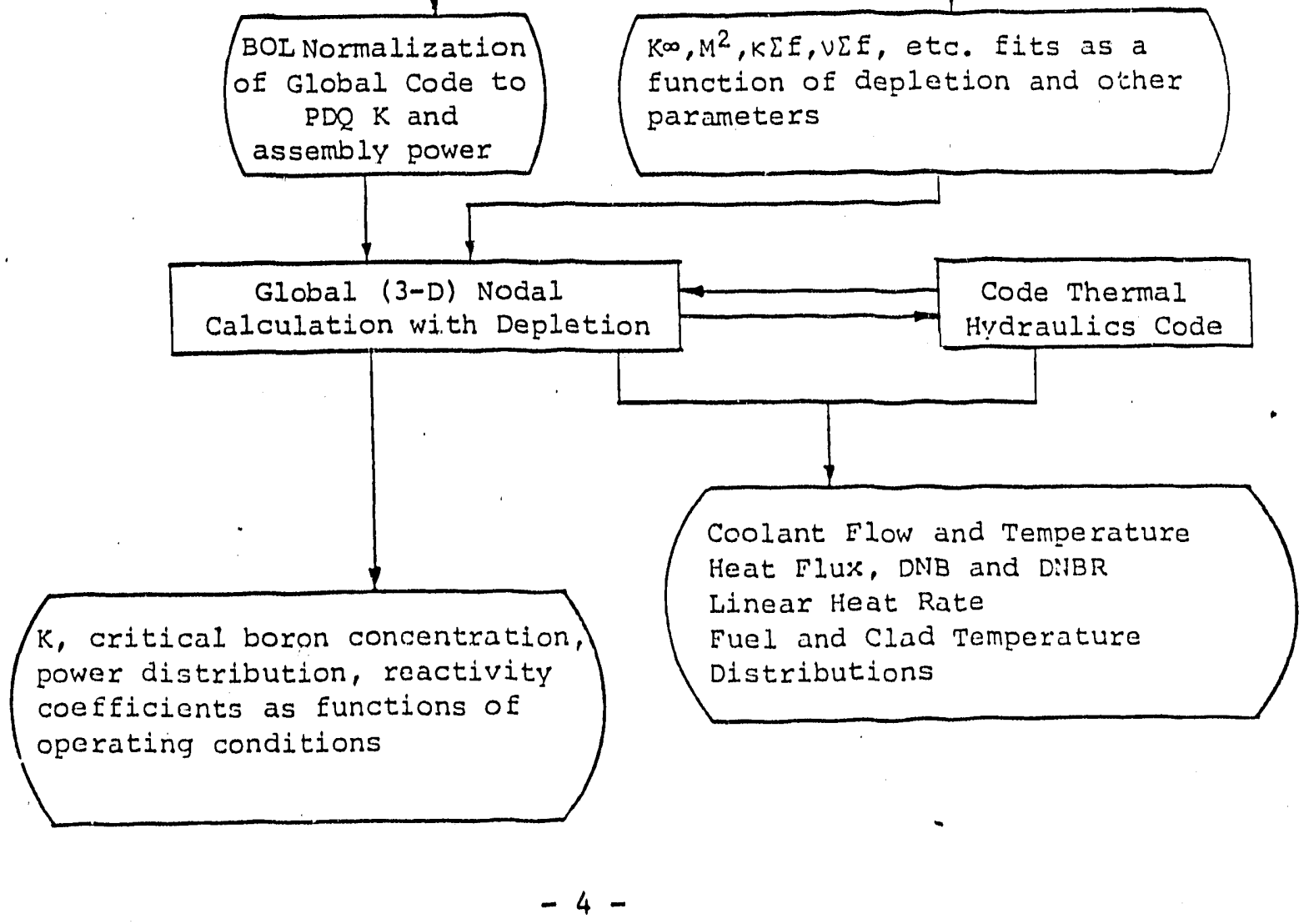

EPRI-CELL Depletion Code - Source of Fuel, Water Hole Representation - 
Section 2.0 of this paper contains summary descriptions of the three selected prototypic codes, CASMO, ORIGIN, and EPRI-CELL. Section 3.0 opens with a summary of a literature survey of the available experimental data base for validating depletion codes prepared by the Oak Ridge National Laboratory ${ }^{(6)}$. This is followed by descriptions of the comparisons made to experimental data of the isotopic content predictions of the three codes. Section 4.0 presents the results of two inter-code comparison studies for reactor physics codes. The section summarizes the isotopic content calculations by two utilities for a standard reactor physics problem developed at the Brookhaven National Laboratory ${ }^{(7)}$. A summary of the accuiracy of the isotopic content calculations is then presented, along with recommendations for further research. 


\subsection{Summary Description of Computer Codes}

\subsection{CASMO-3G}

CASMO-3G ${ }^{(8)}$ is a two-dimensional, multi-group transport theory code for the calculation of eigenvalue, spatial reaction rate distributions, nuclide depletion of pin cells, and depletion of BWR and PWR fuel lattices. CASMO-3G is part of a larger code package $^{(2)}$ that is used for reload design, steady state licensing, and plant support applications. The code is an improved version of the CASMO and CASMO-2 $\operatorname{codes}^{(9,10)}$. It can model cruciform and cluster control rods, water gaps, in-core instrumentation channels, burnable absorber rods, and fuel rods. The code can generate parameters, e.g, transport theory corre cted cross sections, that are used in neutronic codes such as PDQ ${ }^{(5)}$ and SIMULATE-3 ${ }^{(2)}$. The nuclear data library is based on ENDF/B-IV with sorne fission spectra data taken from ENDF/B- $\mathrm{V}^{(11)}$. The library contains 40 or 70 energy group crosssections.

CASMO-3G is divided into seven functional parts:

1- Nuclear data library and resonance calculation,

2- Calculations on unit cells to determine spatial transport and energy spectrum of neutrons in individual pin cells),

3- Calculation of strong absorbers (control rods, Gadolinia in fuel pins, $\mathrm{B}_{4} \mathrm{C}$ burnable poison),

4- Calculation of the 2-D neutron flux within the bundle, the local bundle power distribution, and the total bundle reactivity,

5- Depletion calculation (i.e., isotopic content as a function of burnup),

6- A diffusion theory calculation for the generation of few-group diffusion theory constants for use in other reactor kinetics codes,

7- Gamma transport module, to accurately calculate the energy deposited by gamma rays.

A summary description of the depletion calculation from Reference 6 is given below. Descriptions of the other modules are contained in Reference 6.

In the depletion calculation, the basic burnup chains, with the isotopes linked through absorption and decay, are linearized and the differential burnup equations are solved by a fast analytical treatment. The individually treated fission products account for about 90 
percent of the total fission product absorption. Boron and gadolinium contained in absorber rods are also depleted.

The depletion equations are solved separately for each fuel pin and each burnable absorber pin. The flux level is determined by the average power density. This level is held constant during a depletion step. The depletion calculation for each depletion step is carried out into two partial steps. First, a "predictor" step is made using previous timestep fluxes. The predictor step provides number densities at the advanced time, which are used to calculate fluxes used in a "corrector" step. The final number densities are then given by the average value of the results from the predictor and corrector steps. The size of the timesteps used in the depletion calculation is set in the program using default values, however, the user is allowed to input his own values.

This computer code has been validated against experimental data and calculations from other computer codes. The comparisons of the isotopic data are discussed below in Section 3.3. The code was also compared to experimentally determined eigenvalues, gamma scans of irradiated Quad Cities fuel bundles, and other critical experiments. The code validation was recently reviewed by the Nuclear Regulatory Commission and found acceptable for licensing purposes.

\subsection{ORIGEN2}

ORIGEN $2^{(4)}$ is the latest version of a family of computer codes used for calculating the nuclear composition and characteristics of spent fuel. The input data bases include reactor dependent cross sections, decay data, fission product yields, and neutron production rates. The current version of ORIGEN2 contains cross-section libraries for seren types of reactors, including two for PWRs and two for BWRs. The reactor type, initiai material composition, irradiation history, and decay history are user input.

The ORIGEN irradiation calculation is usually done using many timesteps until the specified burnup is reached. The neutronics are based on simplified point reactor models, with an average flux calculated at each timestep based on the input power level. The point model can be considered as a neutronic calculation model collapsed (in space and energy) from the detailed reactor physics model mentioned in Sections 2.1 and 2.3. To further simplify the neutronics calculation, only the actinide nuclides have burnup dependent cross sections. A series of post-irradiation decay steps may then also be performed.

A variation on the ORIGEN code, OREST ${ }^{(12)}$, was developed at Gesellschaft fur Reaktorsicherheit (GRS) in Germany. This paper was limited to codes used by United States utilities. However, OREST provides an opportunity to look at the modification and use of United States developed code by a foreign uier. In this variation, ORIGEN was combined with the neutron spectrum code, HAMMER, in order to overcome the limitations of the ORIGEN libraries at high burnups or with mixed oxide fuels. HAMMER is used to determine the neutron spectrum, with burnup dependent cross sections, in the actual fuel 
mixture at the beginning of and during burnup. HAMMER also carries out the resonance treatment for the most important uranium and transuranium isotopes.

The OREST code was berichmarked by comparisons to experimental data obtained from the Obrigheim reactor and by an intercode comparison to another ORIGEN variant, KORIGEN. The code was found to predict isotopic content within measurement uncertainties and significantly better than KORIGEN. It is not known how widely used the OREST code is.

\subsection{ARMP/EPRI-CELL}

EPRI-CELL ${ }^{(3)}$ is a pin depletion code. EPRI-CELL is part of the ARMP suite of codes developed by EPRI for use by utilities on various core analyses problems. The ARMP suite of codes is arguably the most widely used core physics code package by United States utilities. EPRI-CELL consists of three main subcodes: GAM, THERMOS, and CINDER. GAM performs the "fast" range neutron calculations; THERMOS the thermal range neutron calculations. THERMOS is spatially dependent, and up to 50 neutron energy groups can be modeled. The CINDER module performs the actual depletion calculation. The depletion is done at each THERMOS spatial point (up to 30 spatial points). The CINDER module contains 90 linear chains: 21 of these chains involving 116 nuclides account for the fuel, transuranic isotopes and burnable poisons which may be present in the calculation; the remaining chains determine the formation of 367 fission product nuclides.

Another cude module in ARMP, EPRI-CPM, also performs depletion calculations. EPRI-CPM is a multi-group, two-dimensional collision probability code. It is used primarily to verify PDQ assembly analyses. EPRI-CPM isotopic calculations have been compared to experimental data. 


\subsection{Comparisons of Code Predicted Isotopic Contents to Experiments}

\subsection{Light Water Reactor Experimental Data Base}

A literature survey of the experimental data available for determining the radiological characteristics of spent fuel was conducted at the Oak Ridge National Laboratory ${ }^{(6)}$. The authors state:

"most of the data available on the composition of (irradiated) reactor fuel were obtained either in fuel reprocessing studies or in destructive testing of fuel by vendors."

The authors of Reference 5 feel that the existing data base is inadequate for the validation of computer codes because of insufficient characterization of initial fuel parameters and irradiation conditions. The report lists results from 16 reactors; a total of 282 analyses of fuel samples giving experimental results for actinides. The authors stated that the H.B. Robinson data had undergone proper quality assurance. No statement was given un the level of quality assurance of the other data. The Zion data which was used to validate the CASMO code was not listed in the report. The German data from Obrigheim reactor used to validate OREST also was not listed.

\subsection{Reactor Power History and Burnup}

\subsection{CASMO-3G Comparisons}

Comparisuss were made to Vermont Yankee and Zion isotopic data as part of the validation of the CASMO-3G code ${ }^{(8)}$. The isotopic composition comparison was made to provide integral verification of the CASMO-3G methodology, with the depletion calculation being one part.

The Vermont Yankee plant is a boiling water reactor. The core consists on rectangular fuel bundles separated by water channels containing cruciform control rods. This arrangement affects the neutron flux locally. Therefore, the comparison of the isotopics was done using three different neutron flux spectra: perturbed, intermediate, and asymptotic. The perturbed neutron spectrum occurs in the vicinity $c^{f}$ the water slots which surround the cruciform control rod positions and near the core reflector. The asymptotic neutron spectrum is found in those regions of the core which are well away from and unaffected by the water gaps and control assemblies. The intermediate spectrum is in those fuel regions between the perturbed and asymptotic regions. The isotopics were measured over a broad range of burnup from approximately 1,200 to $31,000 \mathrm{Mwd} / \mathrm{Mtu}$.

The CASMO-3G calculation modeled an entire Yankee Rowe Core I assembly and zircaloy follower region. Several graphs comparing CASMO-3G calculations for various isotopes to actual plant data ${ }^{(13)}$ were made (Figure 3.1-3.8). The resolution of the graphs 
Figure 3.1

U-235 Atom Percent versus Burnup for Yankee Core I as Calculated by the Casmo Code

\section{'Reference 7}

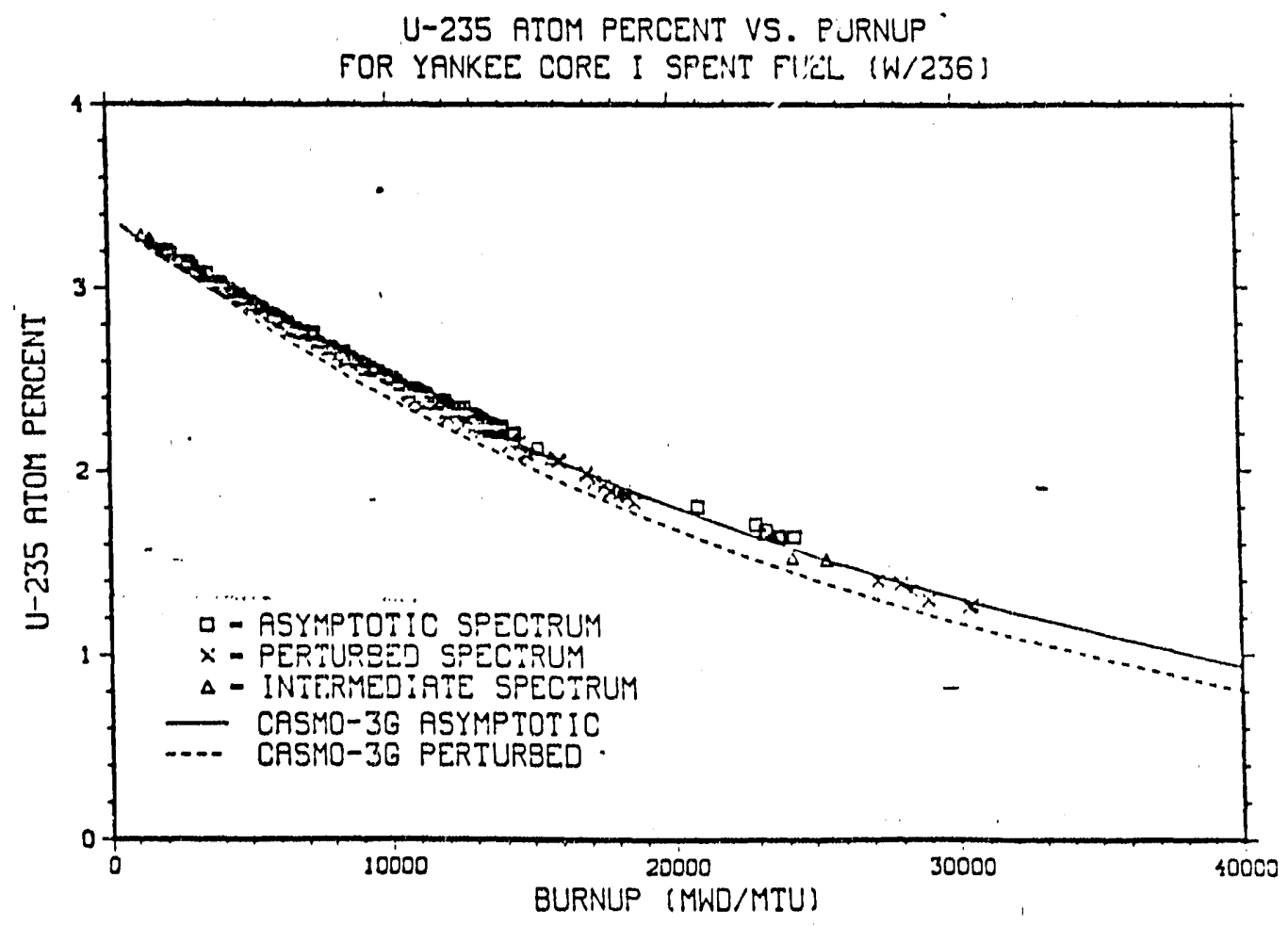


Figure $3.2^{\circ}$

U-236 Atom Percent versus Burnup for Yankee Core I as Calculated by the Casmo Code

\section{'Reference 7}

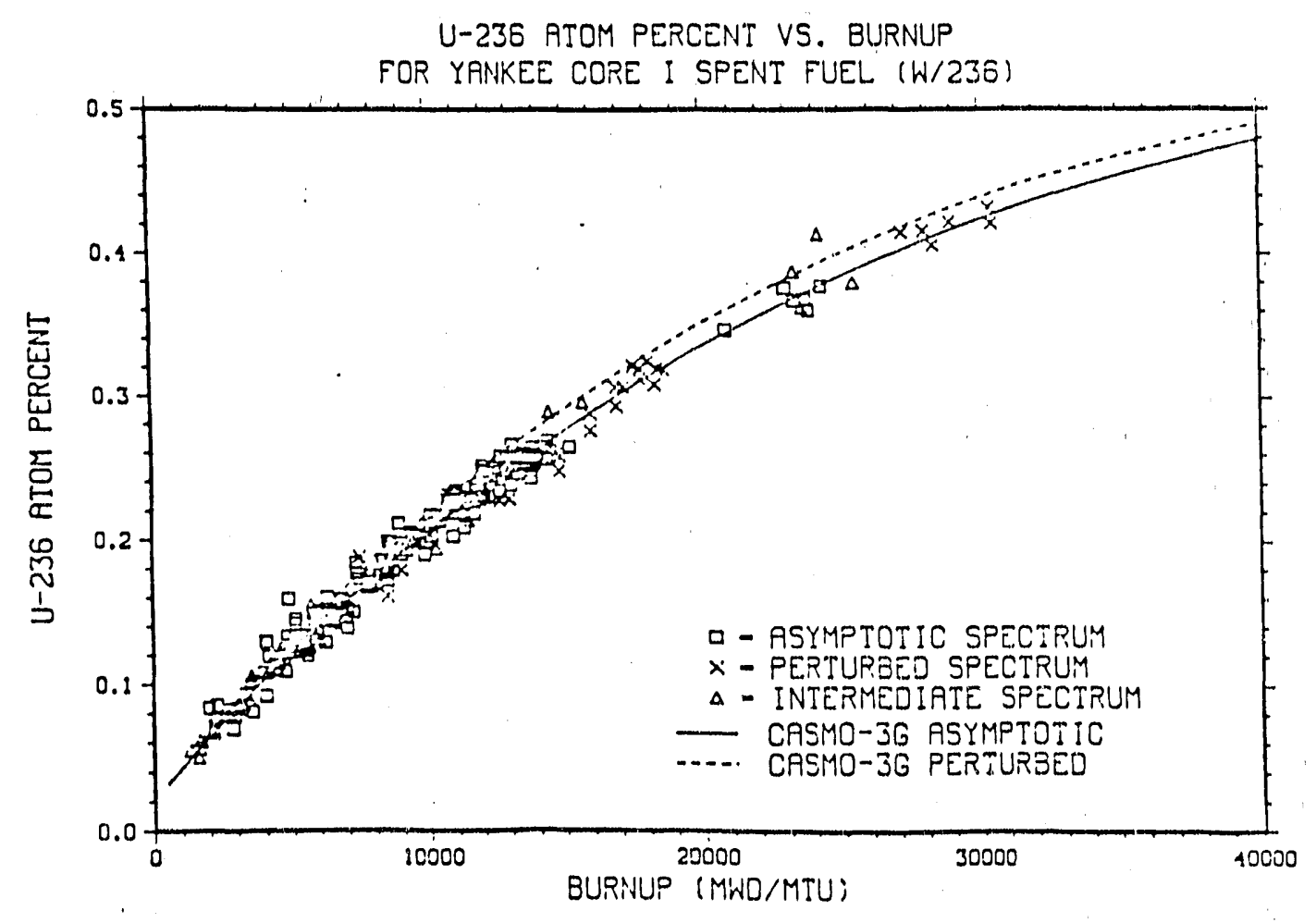


Figure $3.3^{\circ}$

\section{U-238 Atom Percent versus Burnup for Yankee Core I as Calculated by the Casmo Code}

\section{'Reference 7}

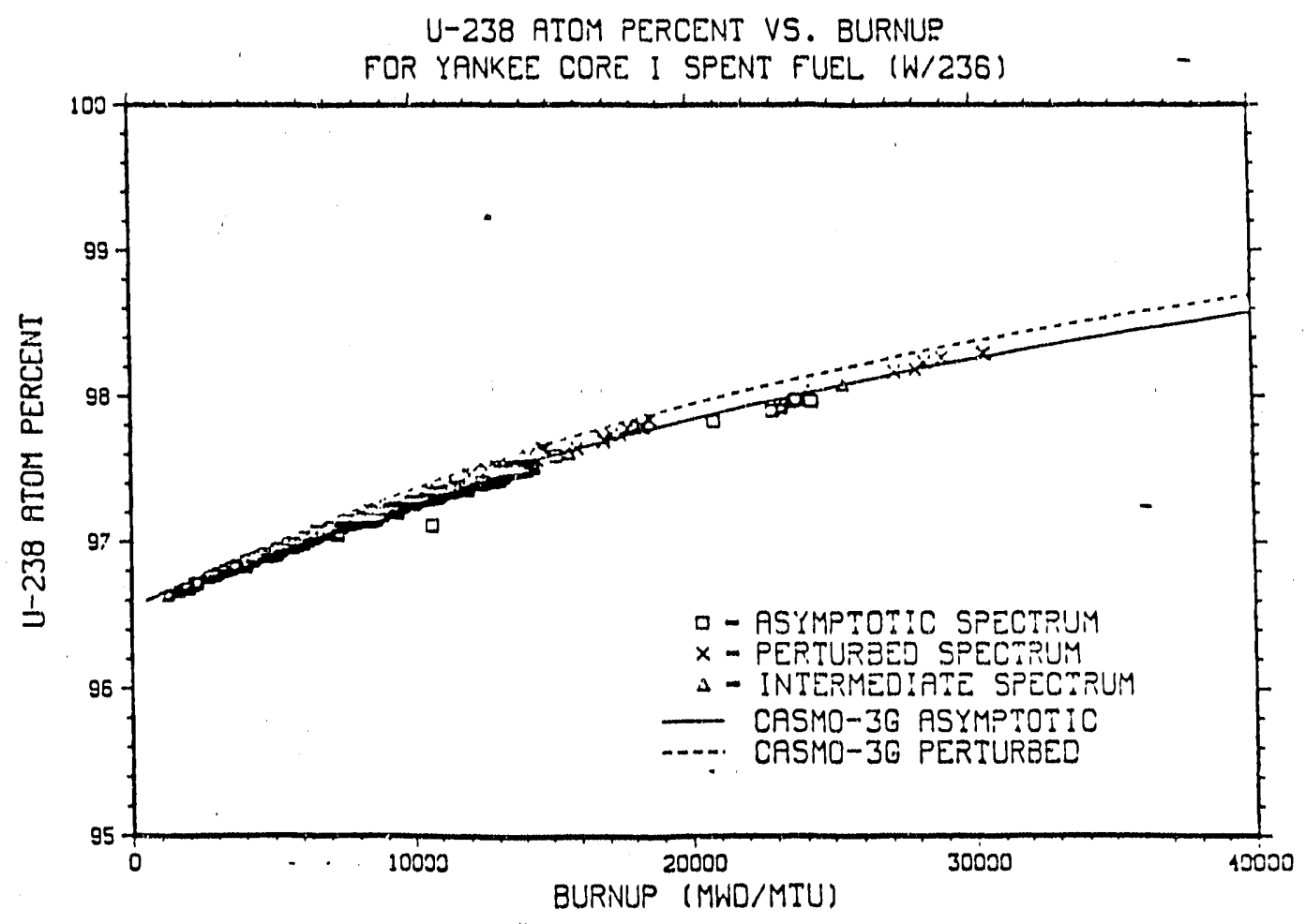


Figure $3.4^{*}$

\section{Pu-239/U-238 Atom Ratio versus Burnup for Yankee Core I as Calculated by the Casmo Code}

\section{'Reference 7}

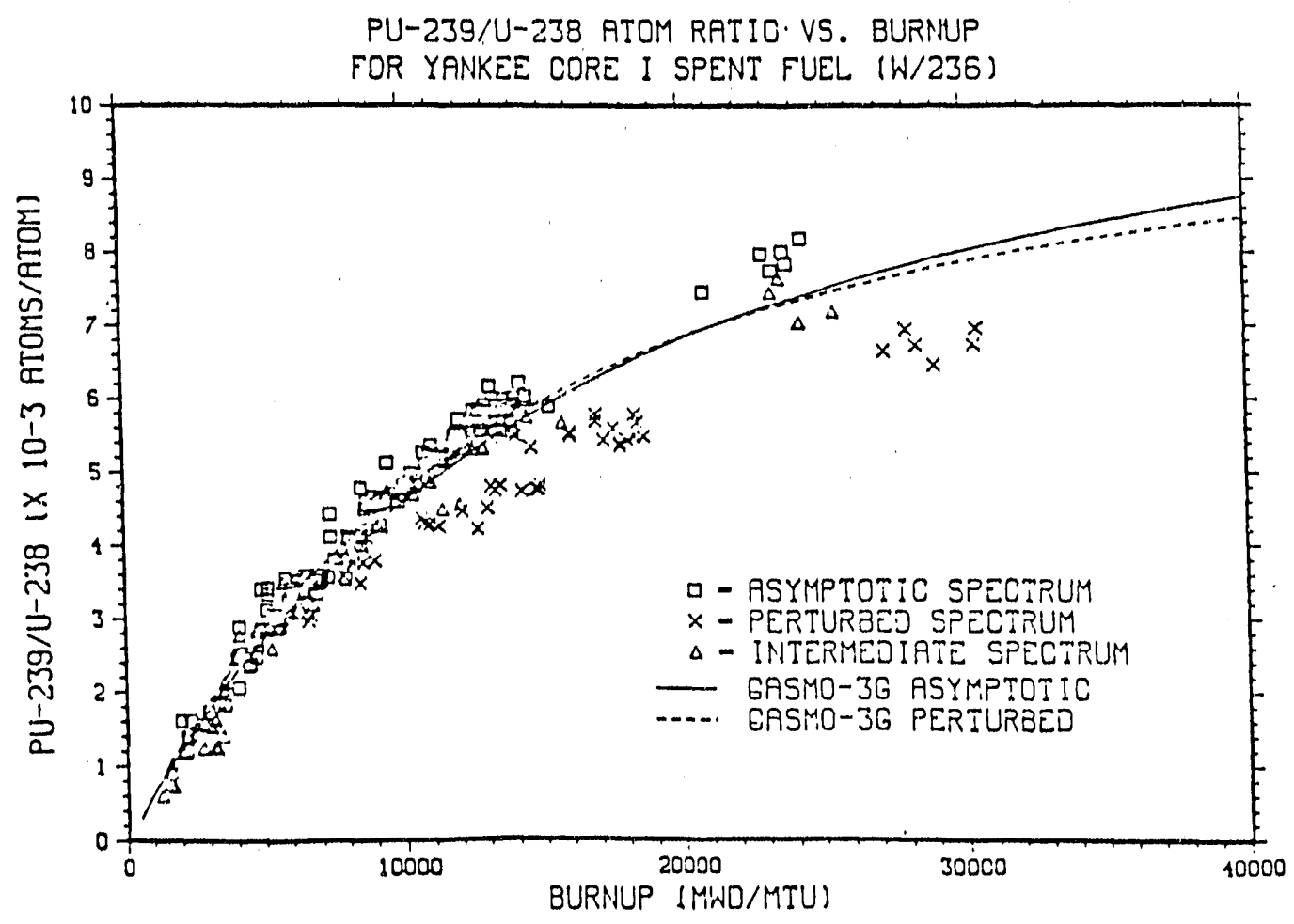


Figure $3.5^{\circ}$

Pu-239 Atom Percent versus Burnup for Yankee Core I as Calculated by the Casmo Code

\section{Reference 7}

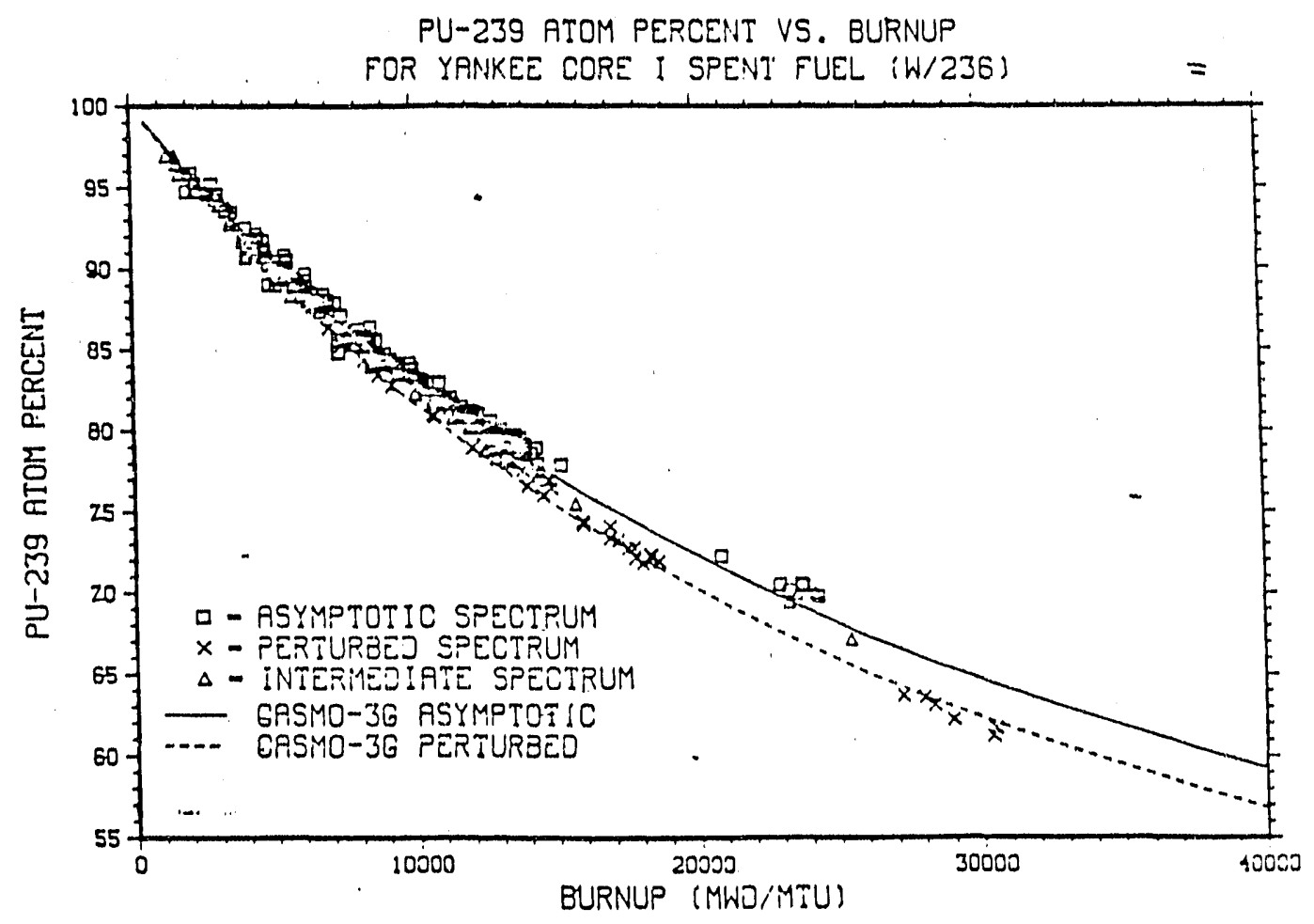


Figure $3.6^{\circ}$

\section{Pu-240 Atom Percent versus Burnup for Yankee Core I as Calculated by the Casmo Code}

\section{:Reference 7}

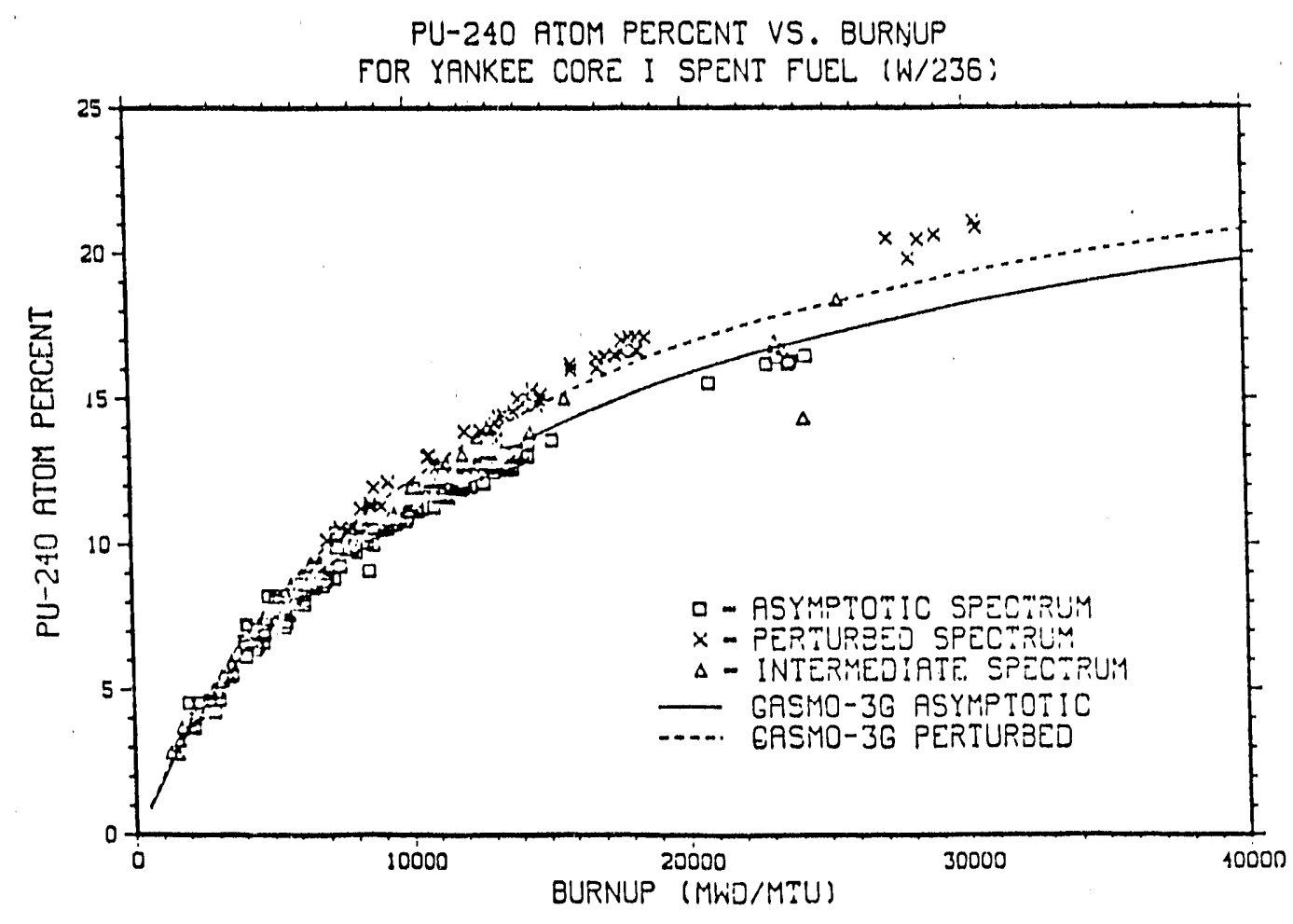


Figure $3.7^{\circ}$

Pu-241 Atom Percent versus Burnup for Yankee Core I as Calculated by the Casmo Code

\section{Reference 7}

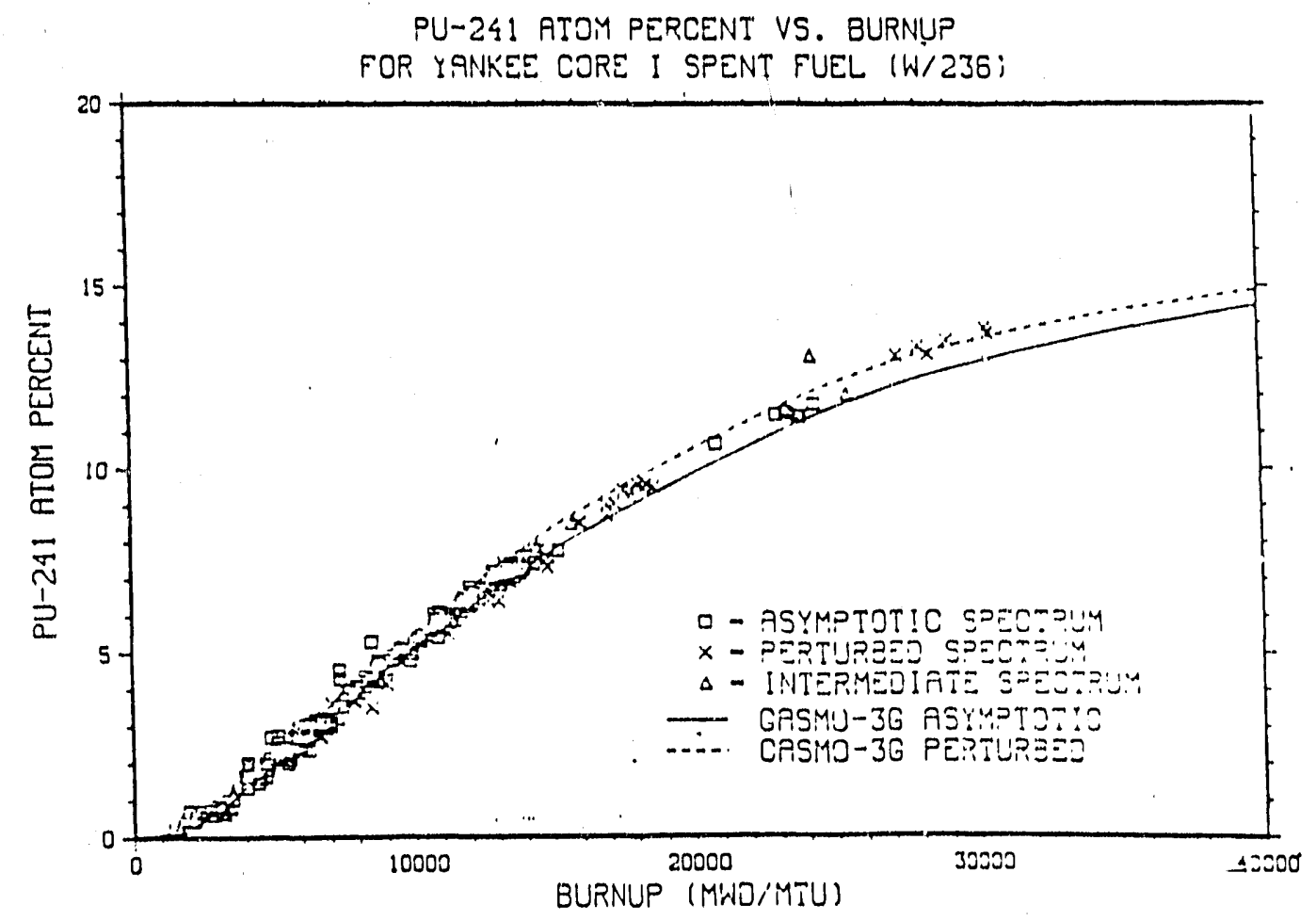




\section{Figure $3.8^{\circ}$}

\section{Pu-242 Atom Percent versus Burnup for Yankee Core I as Calculated by the Casmo Code}

\section{Reference 7}

PU-242 ATOM PERCENT VS. BURNUP

FOR YANKEE CORE I SPENT FUEL (W/235)

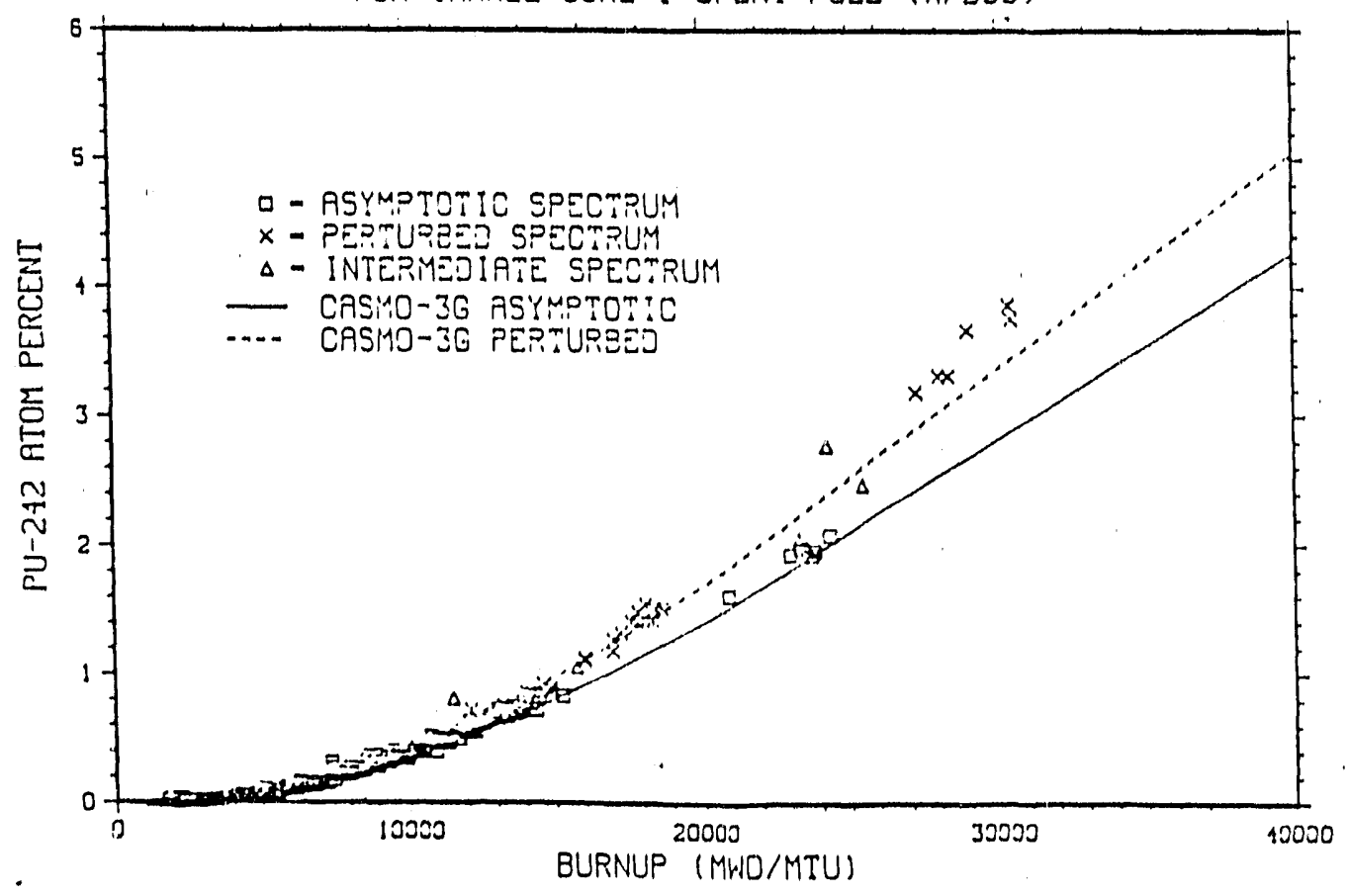


is not fine enough to make a quantitative evaluation of the results, but the CASMO-3G results have a very good qualitative agreement with the Vermont Yankee Data for regions with various neutron spectra in a BWR.

CASMO-3G calculations were also compared to data obtained from the Zion Hot Cell Examination Study ${ }^{(14,15)}$. The Zion plant is a Westinghouse PWR using a $15 \times 15$ assembly. The data were for five different pin locations, located in two different assemblies. The pin locations represent locations in an assembly removed from a water hole (Rod 624), adjacent to a water hole (Rods 642,616, and 614), and diagonally adjacent to a water hole (Rod 699). Therefore, these pins were exposed to different neutron spectra. The burnups ranged for 23,471 MWd/Mtu for Rod 616 to $51,754 \mathrm{MWd} / \mathrm{Mtu}$ for 614 and represent insertion in the core from one to four cycles.

The calculated versus measured results are given Table 3.1. The RMS difference for all the uranium atom ratios is less than 0.04 percent. The root mean square of the difference between the predicted and measured plutonium content for all these rods is less than $1 \%$.

\subsection{ORIGEN Comparisons}

The material in this section is taken from Section 3 of Reference 6. As part of that report, the authors compiled Table 3.2 which lists the comparisons made between ORIGEN predictions and data from H.B. Robinson. They then used this data to prepare Table 3.3 which lists the standard deviations of the ratio of the predicted to measured values for several isotopes. These results were summarized Table 3.4. The plutonium actinides, with the exception of $\mathrm{Pu}-238$ and $\mathrm{Pu}-242$ isotopes, were all predicted within 5\%. It is claimed that the predicted values are within the standard deviations of the experimental data. The authors stress, however, that because many versions of ORIGEN were used in compiling these tables that the results do not provide a full validation of the code. The authors did prepare a similar table based on only one study using a current version of ORIGEN. These results are presented in Table 3.5. Although limited in scope, the results are consistent with earlier work, with even better agreement between experiment and predictions. With Tables 3.3 and 3.5, it can be inferred that the total plutonium mass ( $\mathrm{n}$ be predicted to within $3 \%$ with a standard deviation less than $5 \%$. It is also noted he $s$ that although the errors for $\mathrm{Pu}-238$ and $\mathrm{Pu}-242$ are large, they do not contribute much to the error for the total $\mathrm{Pu}$ mass since their fractions are small for spent fuel.

The Materlals Characterization Center at Pacific National Laboratory is responsible for providing characterized spent fuel, call approved testing materials (ATM), for use in nuclear waster disposal studies. As part of this program, radiochemically measured values of certain isotopes, including actinides, were compared to results obtained using the ORIGEN?

code $^{(16)}$. The two test bundles were from the Calvert Cliffs plant, a PWR. The calculations 


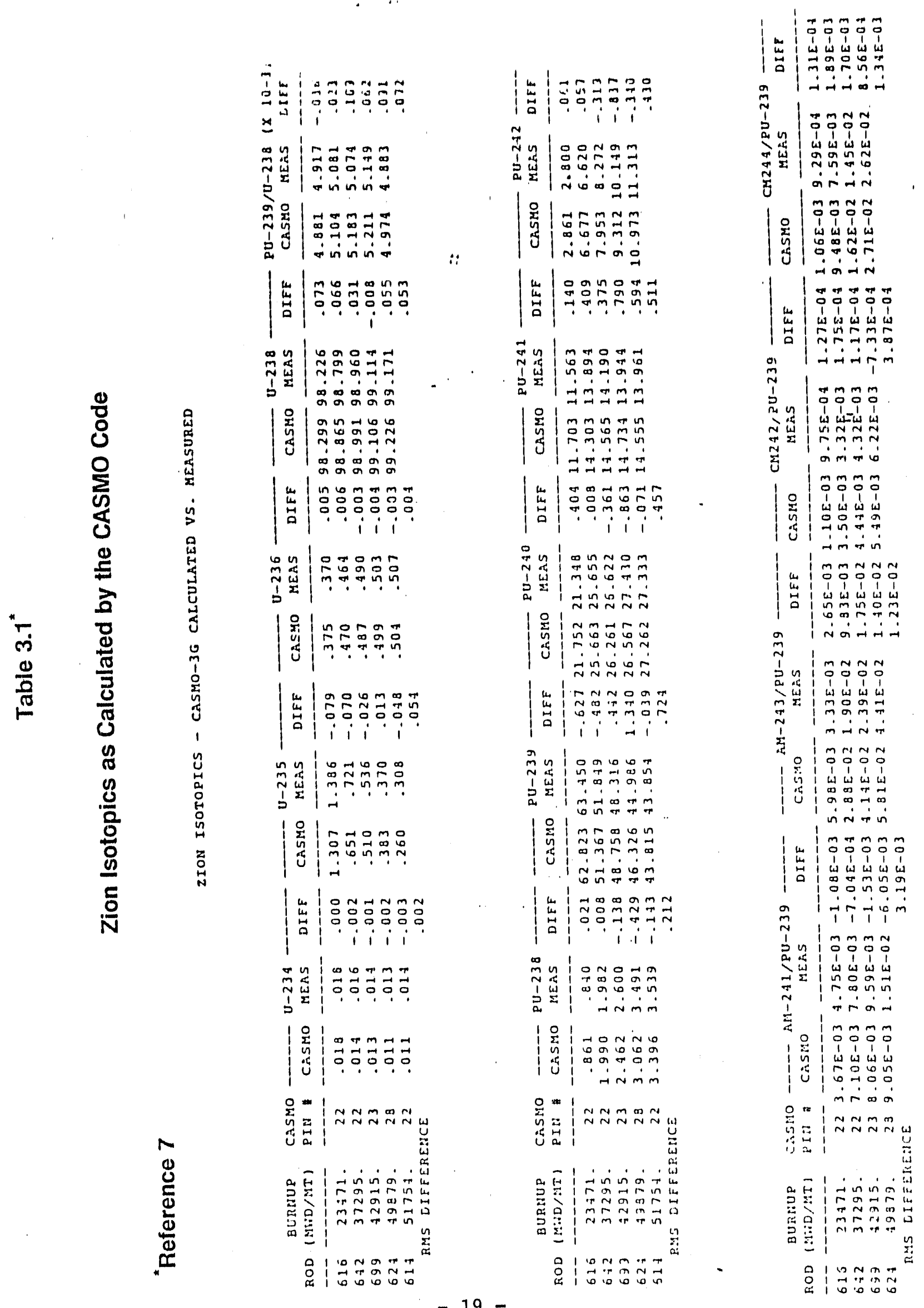


Table 3.2*

Comparison of H.B. Rotinson Fuel Composition Data with ORIGEN Predictions

*Reference 5

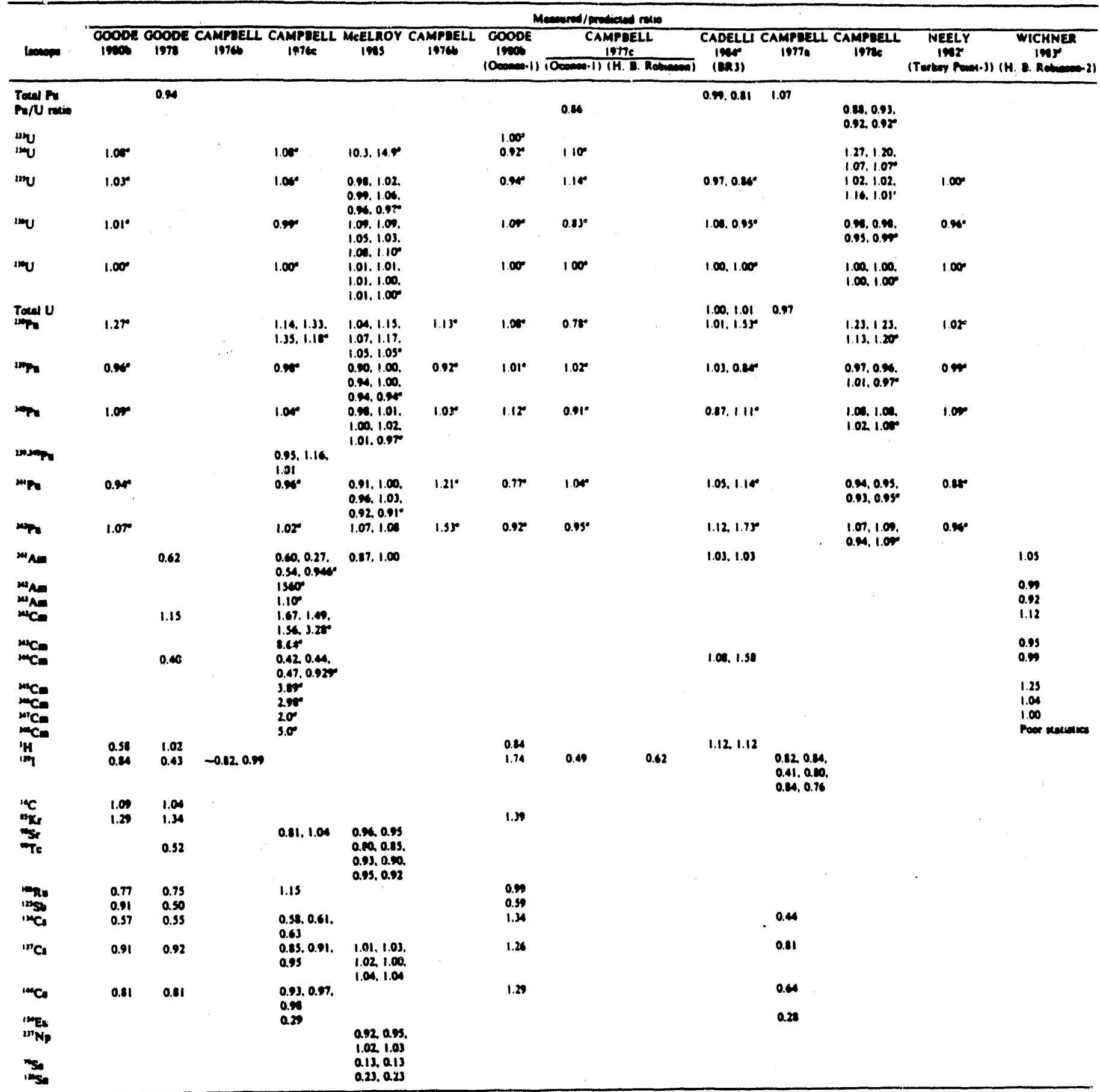

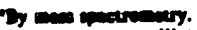

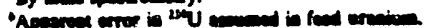

Und ORIOEN2 on

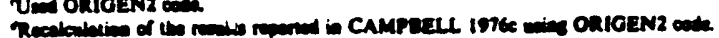


Table 3.3*

\section{ORIGEN Average Measured/Predicted Ratios}

\section{Reference 5}

Arerage measured/predicted ratios

\begin{tabular}{|c|c|c|c|c|c|c|c|c|c|}
\hline Isotope & Low/High & No." & Average & $\mathrm{SD}^{b}$ & Isotope & Low/High & No. ${ }^{a}$ & Average & $S D^{\circ}$ \\
\hline${ }^{234} U^{6}$ & $0.92 / 1.10$ & 8 & 1.10 & 0.10 & ${ }^{235} \mathrm{U}$ & $0.86 / 1.16$ & 17 & 1.01 & 0.07 \\
\hline${ }^{236} \mathrm{U}$ & $0.95 / 1.09$ & 17 & 1.01 & 0.07 & ${ }^{237} \mathrm{~Np}$ & $0.92 / 1.03$ & 4 & 0.98 & 0.05 \\
\hline${ }^{238} \mathrm{Pu}$ & $0.78 / 1.27$ & 21 & 1.15 & 0.15 & ${ }^{239} \mathrm{Pu}$ & $0.84 / 1.03$ & 18 & 0.97 & 0.05 \\
\hline${ }^{240} \mathrm{Pu}$ & $0.87 / 1.12$ & 18 & 1.03 & 0.07 & ${ }^{241} \mathrm{Pu}$ & $0.77 / 1.21$ & 18 & 0.97 & 0.10 \\
\hline${ }^{242} \mathrm{Pu}$ & $0.94 / 1.73$ & 14 & 1.12 & 0.22 & ${ }^{241} \mathrm{Am}$ & $0.27 / 0.946$ & 9 & $0.77^{i}$ & 0.25 \\
\hline${ }^{242} \mathrm{Am}$ & & 1 & 0.99 & & ${ }^{243} \mathrm{Am}$ & & 1 & 0.92 & \\
\hline${ }^{242} \mathrm{Cm}$ & $1.08 / 3.28$ & 7 & $1.69^{4}$ & 0.68 & ${ }^{243} \mathrm{Cm}$ & & 1 & 0.95 & \\
\hline${ }^{24} \mathrm{Cm}$ & $0.40 / 1.12$ & 7 & $0.70^{d}$ & 0.31 & ${ }^{245} \mathrm{Cm}$ & & 1 & 1.25 & \\
\hline${ }^{246} \mathrm{Cm}$ & & 1 & 1.04 & & ${ }^{247} \mathrm{Cm}$ & & 1 & 1.00 & \\
\hline${ }^{248} \mathrm{Cm}$ & & 1 & $0.95^{d}$ & & ${ }^{3} \mathrm{H}$ & $0.58 / 1.02$ & 3 & 0.81 & 0.13 \\
\hline${ }^{129} I$ & $0.43 / 1.74$ & 11 & 0.80 & 0.32 & ${ }^{14} \mathrm{C}$ & $1.04 / 1.09$ & 2 & 1.06 & \\
\hline${ }^{85} \mathrm{Kr}$ & $1.29 / 1.39$ & 3 & 1.34 & 0.04 & ${ }^{79} \mathrm{Se}$ & $0.13 / 0.13$ & 2 & 0.13 & \\
\hline${ }^{90} \mathrm{Sr}$ & $0.81 / 1.04$ & 4 & 0.94 & 0.08 & ${ }^{99} \mathrm{Tc}$ & $0.52 / 0.95$ & 7 & 0.84 & 0.14 \\
\hline${ }^{108} R u$ & $0.75 / 1.15$ & 4 & 0.92 & 0.17 & ${ }^{125} \mathrm{Sb}$ & $0.50 / 0.91$ & 3 & 0.67 & 0.18 \\
\hline${ }^{125} \mathrm{Sn}$ & $0.23 / 0.23$ & 2 & 0.23 & & ${ }^{134} \mathrm{Cs}$ & $0.44 / 1.34$ & 7 & 0.67 & 0.28 \\
\hline${ }^{137} \mathrm{Cs}$ & $0.81 / 1.04$ & 13 & 0.98 & 0.11 & ${ }^{144} \mathrm{Ce}$ & $0.64 / 1.29$ & 7 & 0.92 & 0.19 \\
\hline${ }^{134} \mathrm{Eu}$ & $0.28 / 0.29$ & 2 & 0.28 & & & & & & \\
\hline
\end{tabular}

${ }^{\circ}$ Number of determinations.

${ }^{b} \mathrm{SD}=$ standard deviation.

Two very high ratio (McELROY 1985) were not used.

The latest calculations using ORIGEN2 (see Table A.4) gave ratios of 1.05, 1.12, and 0.99 for ${ }^{241} \mathrm{Am},{ }^{242} \mathrm{Cm}$, and ${ }^{24} \mathrm{Cm}$, respectively. The ${ }^{248} \mathrm{Cm}$ single data point had poor statistics. 
Table $3.4^{\circ}$

Relative Agreement of ORIGEN Predictions for Various Isotopes

\section{'Reference 5}

Relative agreement of ORIGEN predictions for various isotopes

\begin{tabular}{ccc}
\hline $\begin{array}{c}\text { Excellent } \\
\text { (within 10\%) }\end{array}$ & $\begin{array}{c}\text { Fuir } \\
\text { (within } 50 \% \text { ) }\end{array}$ & $\begin{array}{c}\text { Poor } \\
\text { (greater than 50\%) }\end{array}$ \\
\hline${ }^{234} \mathrm{U}$ & ${ }^{242} \mathrm{Cm}$ & ${ }^{79} \mathrm{Se}$ \\
${ }^{235} \mathrm{U}$ & ${ }^{245} \mathrm{Cm}^{4}$ & ${ }^{126} \mathrm{Sn}$ \\
${ }^{236} \mathrm{U}$ & ${ }^{3} \mathrm{H}$ & \\
${ }^{237} \mathrm{~Np}$ & ${ }^{139} \mathrm{Eu}$ \\
${ }^{239} \mathrm{Pu}$ & ${ }^{99} \mathrm{Tc}$ & \\
${ }^{240} \mathrm{Pu}$ & ${ }^{125} \mathrm{Sb}$ & \\
${ }^{241} \mathrm{Pu}$ & ${ }^{134} \mathrm{Cs}$ & \\
${ }^{241} \mathrm{Am}$ & ${ }^{144} \mathrm{Ce}$ & \\
${ }^{242} \mathrm{Am}$ & ${ }^{238} \mathrm{Pu}$ & \\
${ }^{243} \mathrm{Am} \mathrm{m}^{4}$ & ${ }^{242} \mathrm{Pu}$ & \\
${ }^{244} \mathrm{Cm}{ }^{4}$ & ${ }^{85} \mathrm{Kr}$ \\
${ }^{246} \mathrm{Cm} \mathrm{m}^{a}$ & & \\
${ }^{247} \mathrm{Cm}$ & & \\
${ }^{14} \mathrm{C}$ & & \\
${ }^{90} \mathrm{Sr}$ & & \\
${ }^{106} \mathrm{Ru}$ & & \\
${ }^{137} \mathrm{Cs}$ & & \\
\hline
\end{tabular}

${ }^{a}$ Only one experimental determination. 


\section{Table $3.5^{*}$}

\section{Comparison of Measured and ORIGEN Predicted Values for Irradiated H.B. Robinson Fuel}

\section{'Reference 5}

\begin{tabular}{lcc} 
& $\begin{array}{c}\text { Comparison of measured and predicted values } \\
\text { for irradiated fuel composition }\end{array}$ \\
\hline Isotope & $\begin{array}{c}\text { Average ratio } \\
\text { (experiment/ORIGEN2) }\end{array}$ & Standurd deviation \\
\hline${ }^{234} \mathrm{U}$ & 12.6 & Two determinations \\
${ }^{235} \mathrm{U}$ & 0.98 & 0.03 \\
${ }^{236} \mathrm{U}$ & 1.07 & 0.02 \\
${ }^{238} \mathrm{U}$ & 1.007 & 0.005 \\
${ }^{238} \mathrm{Pu}$ & 1.09 & 0.05 \\
${ }^{239} \mathrm{Pu}$ & 0.95 & 0.04 \\
${ }^{240} \mathrm{Pu}$ & 1.00 & 0.02 \\
${ }^{241} \mathrm{Pu}$ & 0.96 & 0.05 \\
${ }^{242} \mathrm{Pu}$ & 1.08 & Two determinations \\
${ }^{237} \mathrm{~Np}$ & 0.98 & 0.05 \\
${ }^{241} \mathrm{Am}$ & 0.94 & Two determinations \\
${ }^{79} \mathrm{Se}$ & 0.13 & Two determinations \\
${ }^{90} \mathrm{Sr}$ & 0.96 & Two determinations \\
${ }^{99} \mathrm{Tc}$ & 0.89 & 0.05 \\
${ }^{126} \mathrm{Sn}$ & 0.23 & Two determinations \\
${ }^{137} \mathrm{Cs}$ & 1.02 & $0.0 !$ \\
${ }^{13}$ & ${ }^{20}$ &
\end{tabular}

${ }^{\circ} \mathrm{H}$. B. Robinson fuel assembly $\mathrm{BO}-5$; initial loading, March 1971: discharged, May 1979; average burnup estimated as 28,050 MIVd/MTU. (Source: J. O. Barner, Characterization of LWVR Spent Fuel MCC-Approved Testing Material--ATM-10I, Pacific Northwest Laboratory, PNL-5109, Rev. 1, June 1985.) 
were run using the ORIGEN2 PWR library, which is based on a fuel with 3.2\% U-235 and a burnup of $33 \mathrm{MWd} / \mathrm{kg} \mathrm{M}$. The two ATMs tested had enrichments of $2.45 \%$ and $2.72 \%$ U-235 with burnups ranging from $18.7 \mathrm{MWd} / \mathrm{kg} \mathrm{M}$ to $46.5 \mathrm{MWd} / \mathrm{kg} \mathrm{M}$. The results for certain actinide isotopes are shown in Table 3.6. The lower burnup fuel used in ATM-103 has better agreement between measurement and calculation, probably because its lower burnup is closer to that used in the ORIGEN2 library. However, even the calculations for the higher burnup ATM-106 is generally within $10 \%$ of the measured values.

The OREST code, a combination of HAMMER and ORIGEN, was validated against assemblies obtained from the Obrigheim reactor as part of the Isotopic Correlation Experiment (ICE) ${ }^{(12)}$. Five assemblies were used with isotopic content determined using radiochemical methods at four different laboratories. The assemblies were processed half at a time, so a total of 40 separate measurements were made. The comparisons for several isotopes are given in Table 3.7. The deviations between experiment and calculation are summarized in Table 3.8, along the measurement uncertainty for the isotope and results from another ORIGEN based code, KORIGEN. As can be seen in Table 3.8, the deviations agree well with measurement uncertainties except for two Pu isotopes. One of these isotopes, $\mathrm{Pu}-242$, was also predicted poorly in the H.B. Robinson comparisons discussed previously.

\subsection{EPRI-CELL Validation}

The EPRI-CELL depletion isotopic calculation was validated against data obtained from the Yankee Rowe, Saxton, and Robinson-2 reactors ${ }^{(3)}$. Two sets of Yankee Rowe data were used: stainless steel clad pins and zircaloy clad pins. The zircaloy clad pin data was limited. The Saxton and Robinson-2 comparisons were made with an additional code, EPRI-CPM (also part of the ARMP package), being used in conjunction with EPRI-CELL. For the Saxton data, EPRI-CPM was used to provide six of the heavy element cross sections. The Robinson-2 data were for a single pin in an assembly with burnable poison pins. EPRICELL is a single fuel pin depletion code that represents a fuel bundle with a single average pin. Therefore it was necessary to calculate correlation factors using EPRI-CPM, which uses a full 2-D representation of a fuel bundle and can therefore account for the presence of burnable poison rods, for use in EPRI-CELL.

The predicted to experiment comparisons were made on the basis of isotopic ratios. Comparisons on this basis reduce the data scatter at high burnups. The scatter in absolute isotopic data increases with burnup. This basis also reduces the sensitivity of the calculation to various input parameters. Therefore, these comparisons, while useful for the code validation, are of limited value for this study. The comparisons do provide insight into the overall accuracy of the code. 
Table 3.6 Ratios of Predicted-to-Measured Values of Nuclides in Fuel
from ATM-103 and ATM-106 (Refs. 2 and 3)

\begin{tabular}{|c|c|c|c|c|c|c|}
\hline \multirow[b]{3}{*}{ Nuclide } & \multicolumn{3}{|c|}{ ATM-103 } & \multicolumn{3}{|c|}{$.1714-106^{\circ}$} \\
\hline & Ratio at & Given fue Burnuo, & II:Td $/ \mathrm{kaH}$ & Ratio de & Given ruel durnu & $40 . .9 d / \mathrm{kan}$ \\
\hline & 33.2 & 20.6 & 10.7 & 70.5 & 3.0 & 1.3 .5 \\
\hline $234_{U}$ & 1.02 & 1.11 & 1.06 & NA & iA & HA \\
\hline $235_{u}$ & 1.06 & 1.04 & 1.04 & 1.37 & 1.23 & 1.20 \\
\hline $236 \mathrm{U}$ & 0.93 & 0.93 & 0.93 & 0.96 & 0.95 & 0.96 \\
\hline $238_{U}$ & 0.99 & 0.98 & 0.99 & 1.00 & 0.99 & 0.99 \\
\hline 238 pu & 0.98 & 0.94 & 0.84 & 1.10 & 1.12 & 1.11 \\
\hline${ }^{239} \mathrm{Pu}$ & 1.06 & 1.02 & 1.02 & 1.20 & 1.18 & 1.18 \\
\hline $240 \mathrm{Pu}$ & 1.02 & 1.02 & 1.03 & 0.98 & 1.01 & 1.02 \\
\hline $241 \mathrm{Pu}_{\mathrm{u}}$ & 1.05 & 1.02 & 1.02 & 1.22 & 1.16 & 1.14 \\
\hline 242 pu & 0.89 & 0.93 & 0.93 & 0.83 & 0.87 & 0.89 \\
\hline $237 \mathrm{Yp}$ & 1.14 & 0.98 & 1.04 & 1.41 & 1.35 & 1.37 \\
\hline $24 !_{\text {im }}$ & 1.01 & 1.02 & 1.02 & 0.76 & 1.02 & 1.12 \\
\hline${ }^{243} \mathrm{~cm}+{ }^{244} \mathrm{~cm}$ & 0.99 & 0.93 & 0.84 & 1.02 & 1.01 & 1.08 \\
\hline${ }^{79} \mathrm{Se}$ & 6.67 & 6.25 & 6.25 & 9.33 & 7.14 & 8.33 \\
\hline${ }^{90} \mathrm{Sr}$ & 0.98 & 0.98 & 0.97 & 1.00 & 1.00 & 0.98 \\
\hline${ }^{99} T C$ & 1.01 & 1.01 & 0.97 & 1.37 & 1.39 & 1.41 \\
\hline${ }^{126} \mathrm{Sn}$ & 4.35 & 4.17 & 4.34 & 5.26 & 5.55 & 5.00 \\
\hline $129 j^{c}$ & 0.85 & 0.91 & 0.89 & 1.08 & HA & 1.19 \\
\hline${ }^{135} \mathrm{Cs}$ & 1.02 & 1.00 & 0.99 & 1.08 & 1.11 & 1.08 \\
\hline${ }^{137} \mathrm{Cs}$ & 0.97 & 0.96 & 0.95 & 0.94 & 0.99 & 0.95 \\
\hline
\end{tabular}

${ }^{a}$ Enrichment was $2.72 \mathrm{z} 235_{\mathrm{U}}$. Examined $6.5 \mathrm{yr}$ after discharge on october $18,1990$. benrichment was $2.45 \%$ 235 . Examined 6.7 yr after discharge on october $18,1980$. cThe ${ }^{129}$ I was measured in other samples with slightly different burnups: 33.0 $\mathrm{MWd} / \mathrm{kgM}, 25.5 \mathrm{MWd} / \mathrm{kg} \mathrm{M}$, and $15.6 \mathrm{MWd} / \mathrm{kg} \mathrm{M} \mathrm{in} \mathrm{ATM-103,} \mathrm{and} 46.5 \mathrm{MWd} / \mathrm{kg} \mathrm{M}$ and 29.5 $\mathrm{MWd} / \mathrm{kg} \mathrm{M}$ in ATM-106.

$\mathrm{NA}=$ Not available. 


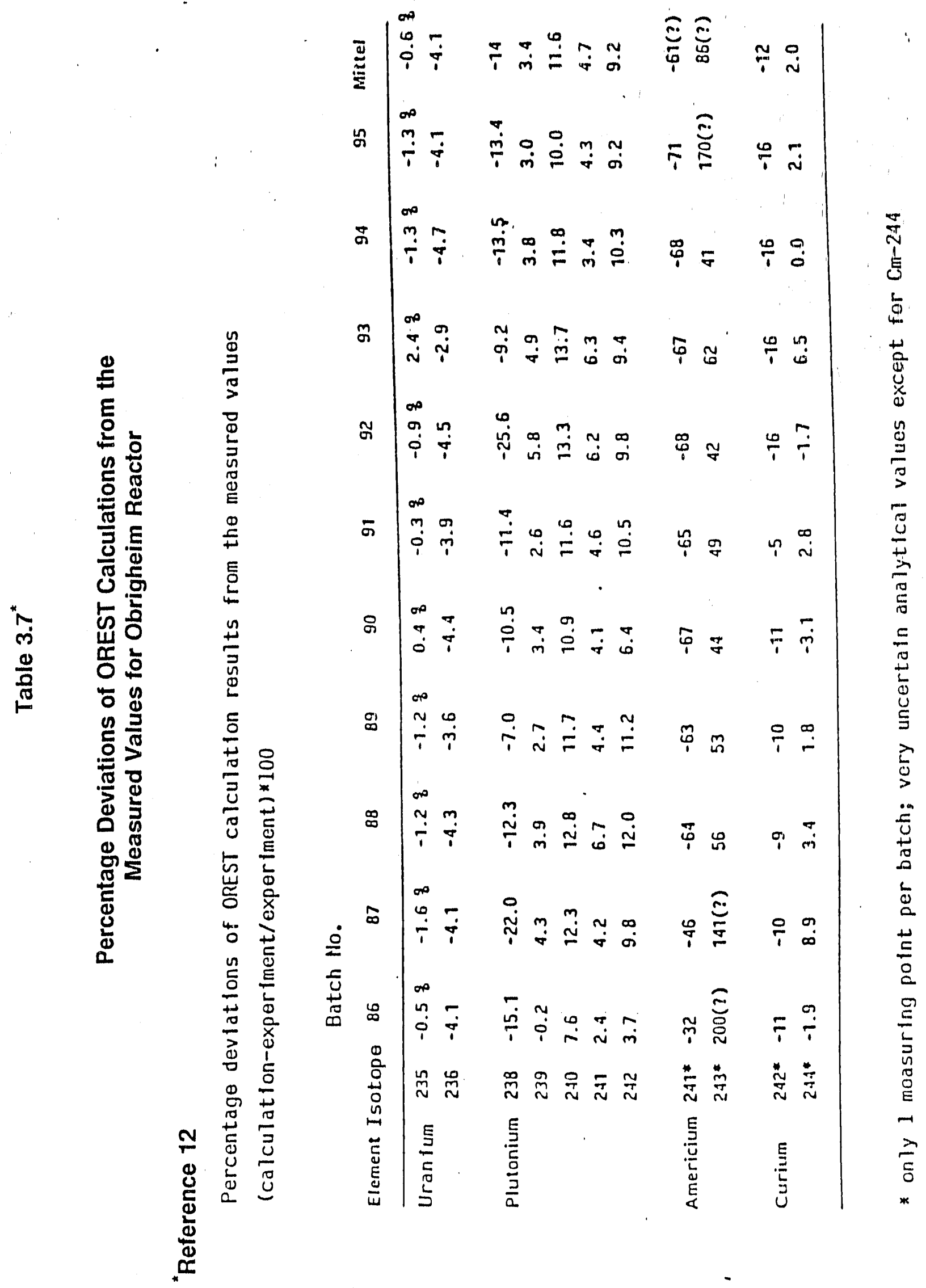


Table $3.8^{*}$

Comparison Between Experiment and OREST Calculations for Obrigheim Reactor

Reference 12

Comparison between experiment and calculation as regards nuclide concentrations in fuel assemblies 168 through 176

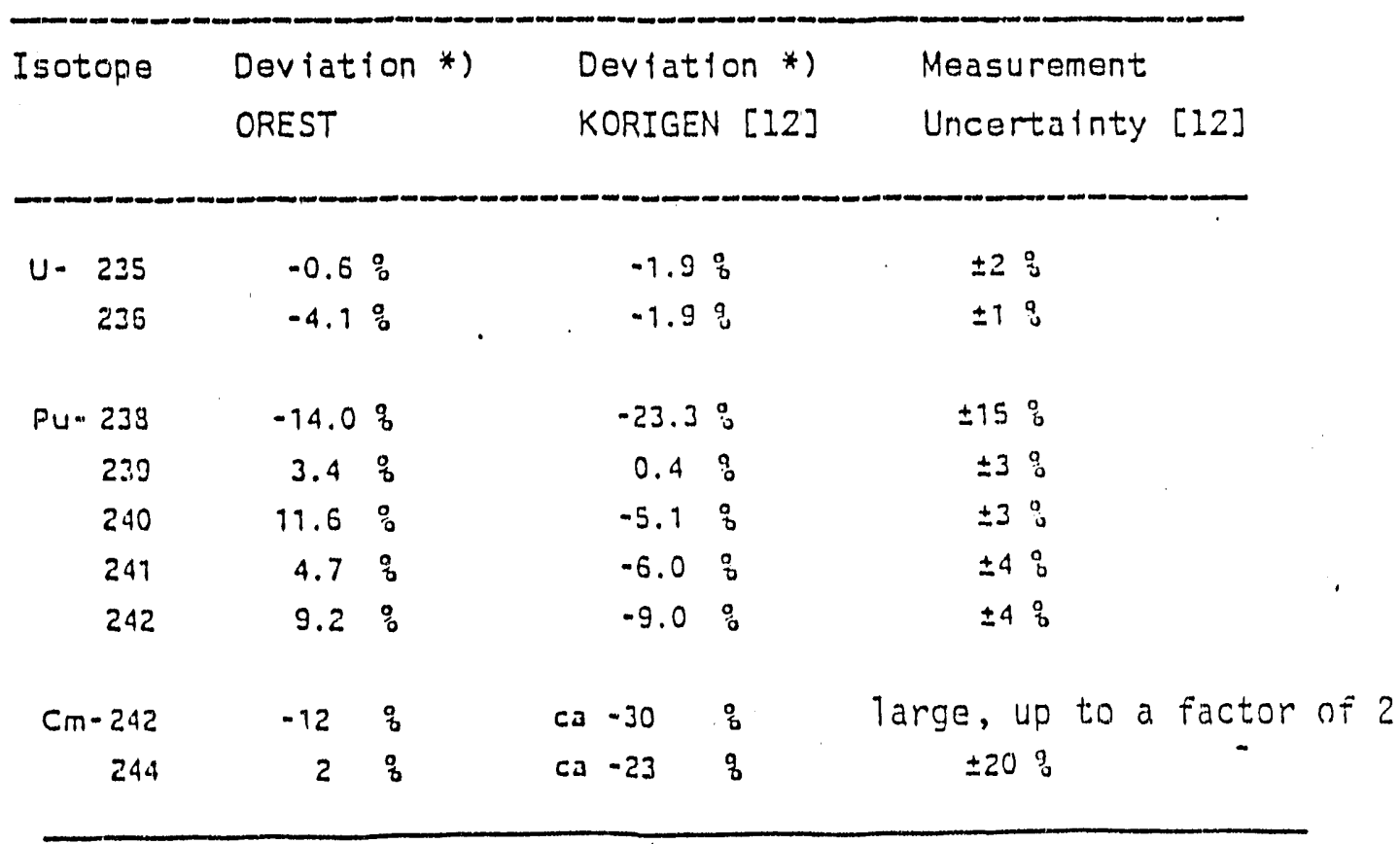

*) Deviation in percent equivalent to (calculation-experiment)/experiment*100 
The Yankee Rowe comparisons were presented as a set of curves showing the calculation versus experimental data. Figure 3.9 shows results for the isotopic ratio of $\mathrm{Pu}-$ 239/Pu-240 for the stainless steel clad pins; Figure 3.10 the isotopic ratios for $\mathrm{Pu}-239 / \mathrm{Pu}-$ 240, Pu-240/Pu-241, and $\mathrm{Pu}-241 / \mathrm{Pu}-242$. The graphs do not allow for a quantitative comparison of the results, but the calculations appear to agree well with the experimental data.

The Saxton data was from Core II and consisted of 20 samples with burnups ranging from 7,000 to 22,000 MWD/MTU. The results for one pin are summarized in Table 3.9. The absolute isotopic data in the upper part of the table has been corrected for burnup. That is the comparisons were adjusted back to the end of the irradiation period, hence, the $0 \%$ uncertain.y in the U-238 and Pu-239 concentrations. The atom ratios in the lower part of the table are uncorrected and correspond to a particular time after shutdown. The results are very good for all isotopes except Pu-238 (which has a large experimental uncertainty), Pu-242 (which is consistently underpredicted by EPRI-CELL), and the Np-237/U-238 ratio.

The Robinson comparison was for a single rod with an average exposure of 18,000 MWD/MTU. The rod was divided into three segments with exposures of 24,570 MWD/MTU, 27,620 MWD/MTU, and 30,920 MWD/MTU. The measurement accuracy was within $\pm 5.1 \%$. The middle segment was near a spacer grid, which could not be modeled with EPRI-CELL, so the comparisons were limited to the other two sections. Table 3.10 shows the comparisons for these two exposures for three isotopic ratios. In all cases, the predictions agree well with the experiments. 
Figure $3.9^{*}$

Pu-239/Pu-240 Atom Ratio versus Accumulated Fissions for Yankee Core I as Calculated by the EPRI-Cell Code

\section{"Reference 2}

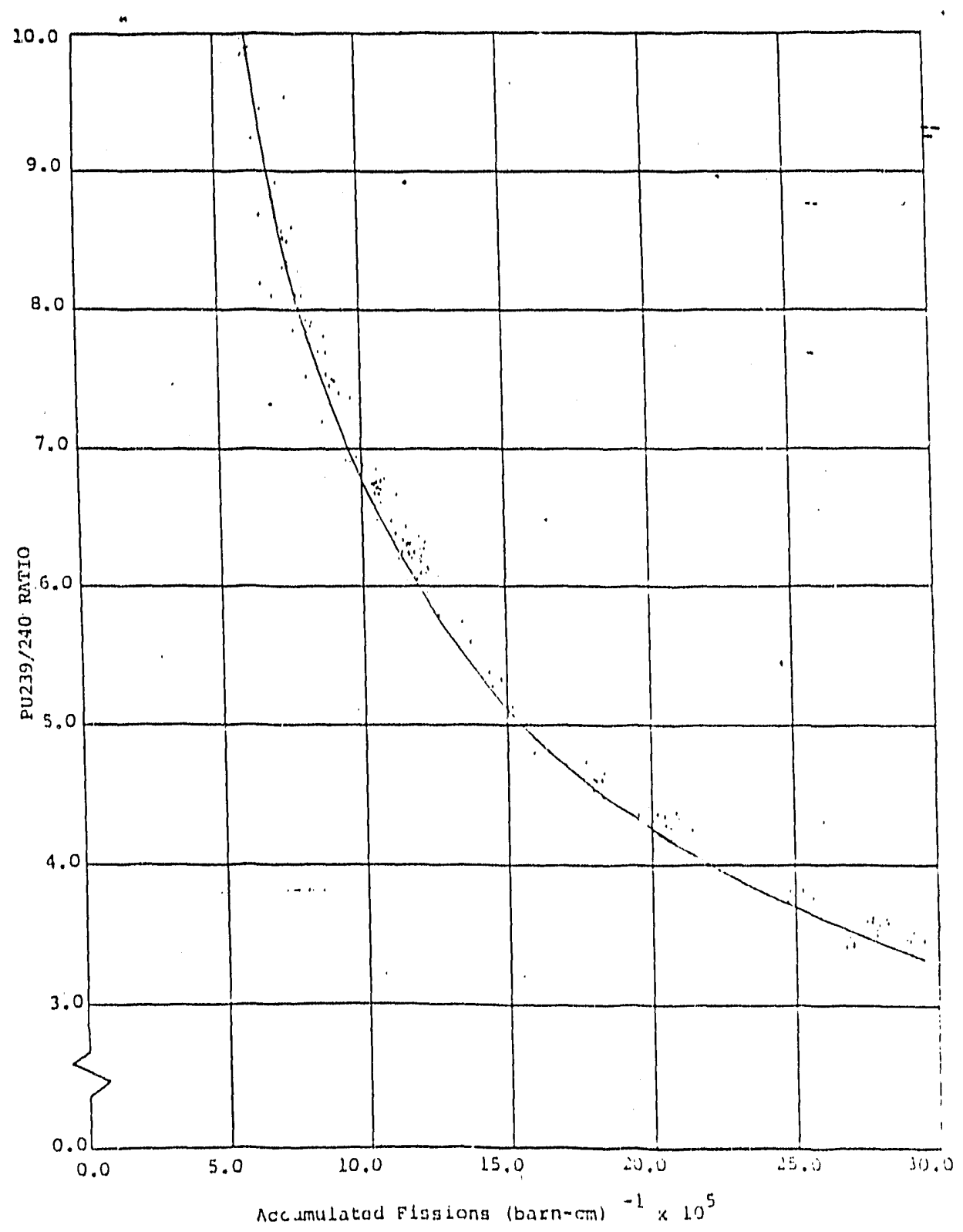

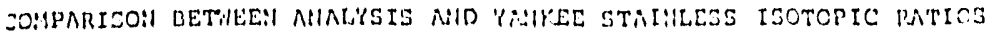




\section{Figure $3.10^{*}$}

\section{Plutonium Isotopic Ratios versus U-235 Fractional Depletion for Yankee Core V Zircalloy Assemblies as Calculated by the EPRI-Cell Code}

\section{Reference 2.}



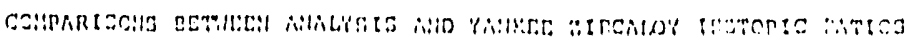




\section{Table $3.9^{\circ}$}

\section{"Reference 3}

Comparison Between EPRI-CELL and SAXTON Expeilmental Data

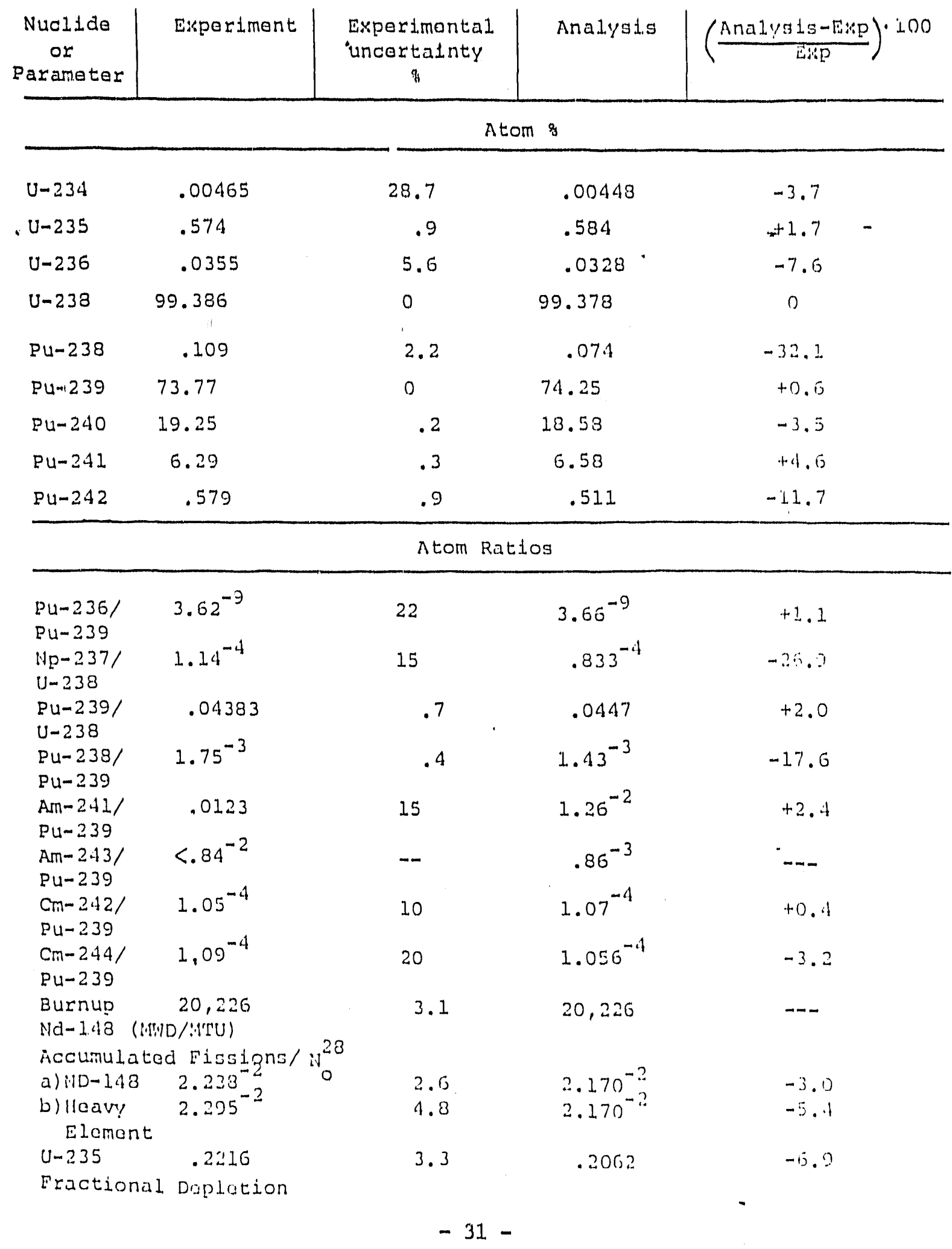




\section{Table 3.10}

\section{Comparison of Isotopic Ratios Calculated by EPRI-CELL}

and Experimental Data for H.B. Robinson

\section{'Reference 3}

Variation in Isotopic Ratios with Eisosura

\section{statod \\ Exposura \\ $(\sin / 4 \sin 3)$}

$2 \cdot 7,700$

30,220

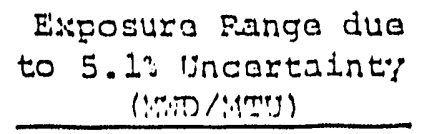

$23,350-25,350$

$29,2 \div 0-32,500$
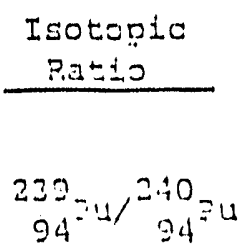

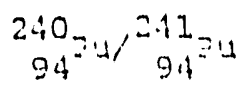

$2+1+21 \% 92=12$

$3.03 \pm .27$

$222=4 / 240.24$

$2.15+.05$

$240=1 / 24124$

$1.79+.05$

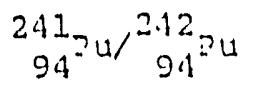

$2.33+.19$

$2.5 j \pm .107$
Values cE EZシニーCẼニ

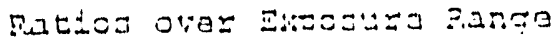

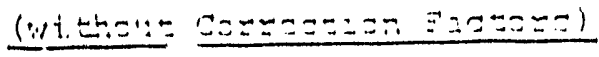

Yoasuramen $\therefore .27-2.9$

$1.21-1.33$

Z. $\div-3 . \Xi \pm$

$1.2 \div-2.11$

$1.73-1.73$

$2.3 \div-2.63$ 


\subsection{Comparisons to BNL Standard Physics Problem}

The Brookhaven National Laboratory has developed a series of standard problems for the evaluation of reactor physics codes. The problem consists of two fuel assembly lattices are to be evaluated at several statepoint conditions and compared to a BNL computer solution. Since the problem is "artificial", no experimental data exists to compare against. The problem, though, does provide insight into the consistency of the various computer codes used.

Isotopic content results from the two computer codes, CASMO and LEOPARD, are summarized in Table 4.1. The error measurements are only approximate in order to maintain the integrity of the standard problem solution. The comparisons are quite good, with the largest deviation being $10 \%$. 
Table 4.1

Comparison Between CASMO and LEOPARD Results for Brookhaven National Laboratory

BNL STANDARD PROBLEM COMPARISONS

CASMO

LEOPARD

U-235

5 *

6

U-238

.1

2

Pu-239

5

1

$\mathrm{Pu}-240$

5

$-7$

Pu-241

5

$-1$

Pu-242

3

10

-ERROR - CrBNL - CalC)/ BNL X 100\% 


\subsection{Conclusions}

Table 5.1 summarizes key comparisons for the various codes. With the exception of the SAXTON data, the actinide isotopic content is calculated accurately for most isotopes regardless of the code chosen. The results for the CASMO and ORIGEN codes are all within $10 \%$ of the expected values; the majority of the isotopes are within 5\%. The EPRICELL comparison to SAXTON is less satistactory. In this case, the calculated actinide isotopic content for Pu-238, Pu-242, and Np-237 are larger than 10\%. This may be due to the non-prototypic nature of the SAXTON fuel samples. The OREST results illustrate that even a user-modified code can be expected to give reasonably accurate results.

Table 5.1 does not show what the experimental uncertainty is in the measurement for actinide isotopic content. Typically, the measurement error ranges from $\pm 2-10 \%$ depending on the isotope and the measurement technique used. Additionally, the table does not show the absolute atomic percentage of each isotope. Isotopes present in small amounts may have a larger measurement error than isotopes present in large quantities.

To illustrate the effect of isotope abundance on the total uncertainty of the calculationmeasurement error, the ORIGEN results for the plutonium isotopes were examined in greater detail. The results are summarized in Table 5.2. In this table, it can be seen that the isotopes with the largest error, Pu-238 and Pu-242, occur in very small quantities. Therefore, their contribution to the overall error is also small. As a result, the overall ORIGEN error for the plutonium isotopes is only $3 \%$, with a standard deviation of only $\pm 3 \%$.

The ORIGEN results also show that for significant burnups in fuel bundles actually exposed over their lifetimes in power reactors, no detailed neutron flux calculation, such as used in CASMO or EPRI-CELL, is needed. There are two reasons for this. First, as burnup increases, the actinides very quickly obtain equilibrium or near equilibrium values. Therefore, crrors in the neutron flux shape or local power level do not lead to large errors in actinide isotopic content. Second, it is standard utility practice to place the bundles in the core so that a uniform burnup is obtained. Specifically, over the lifetime of the bundle, it is usually placed in two or three different locations in the core so that as uniform as possible a flux profile is obtained. Thus, no one bundle is placed near control rods, or other areas, where its flux profile is severely distorted for its entire lifetime.

The scope of this work was limited to a review of the current literature. This search yielded several reports that provided comparisons between computer codes and experimental data as part of validation studies. None of these studies looked in great detail at the sensitivity of the codes to various input parameters. For exampie, utility reported assembly burnups, a significant input to the computer codes, are calculated very accurately ${ }^{(17)}$. A 
Table 5.1

Accuracy of Calculated Actinide Isotopic Contents

\begin{tabular}{|c|c|c|c|c|c|c|}
\hline Code & CASMO & CASMO & LEOPARD & ORIGEN & OREST & $\begin{array}{l}\text { EPR I - } \\
\text { CELL }\end{array}$ \\
\hline DATA & ZION & BNL & BNL & $\begin{array}{l}\text { H.B Rob- } \\
\text { inson }\end{array}$ & Obergheim & SAXTON \\
\hline$U-235$ & 8 & $\sim 5$ & $\sim_{6}$ & -2 & -.6 & 1.7 \\
\hline$U-236$ & 0.4 & $x$ & $x$ & 7 & -4.1 & -7.6 \\
\hline$U-238$ & 0.05 & $\sim .1$ & $\sim_{2}$ & 0.7 & $x$ & 0 \\
\hline Pu-238 & 5 & $x$ & $x$ & 9 & -14 & -32.1 \\
\hline Pu-239 & 1 & $\sim 5$ & $\sim 7$ & -5 & 3.4 & 0.6 \\
\hline Pu-240 & 1 & $\sim 5$ & $\sim 7$ & 0 & 11.6 & -3.5 \\
\hline$P u-241$ & 3 & $\sim 5$ & $\sim-1$ & -4 & 4.7 & +4.6 \\
\hline PU-242 & 4 & $\sim_{3}$ & $\sim 10$ & 8 & 9.2 & -11.7 \\
\hline NP-237 & $x$ & $x$ & $x$ & 2 & $x$ & -26.9 \\
\hline
\end{tabular}


Table $5.2 a$

\begin{tabular}{|l|c|c|c|c|c|}
\hline & Pu-238 & Pu-239 & Pu-240 & Pu-241 & Pu-242 \\
\hline $\begin{array}{l}\text { Isotope } \\
\text { Fraction (8) }\end{array}$ & 1 & 58 & 25 & 9 & 7 \\
\hline Error & 1.15 & 0.97 & 1.03 & 0.97 & 1.12 \\
\hline Relative Error & 1.15 & 56.26 & 25.75 & 8.73 & 7.84 \\
\hline $\begin{array}{l}\text { Standard } \\
\text { Deviation }\end{array}$ & 0.15 & 0.05 & 0.07 & 0.10 & 0.22 \\
\hline \begin{tabular}{l} 
Variance \\
\hline $\begin{array}{l}\text { Mean Error for } \\
\text { all pu Isotopes }\end{array}$
\end{tabular} & 0.9973 & 7.91 & 3.25 & 0.76 & 2.97 \\
\hline
\end{tabular}

${ }^{a}$ From Table 3.3

Table $5.2 b$

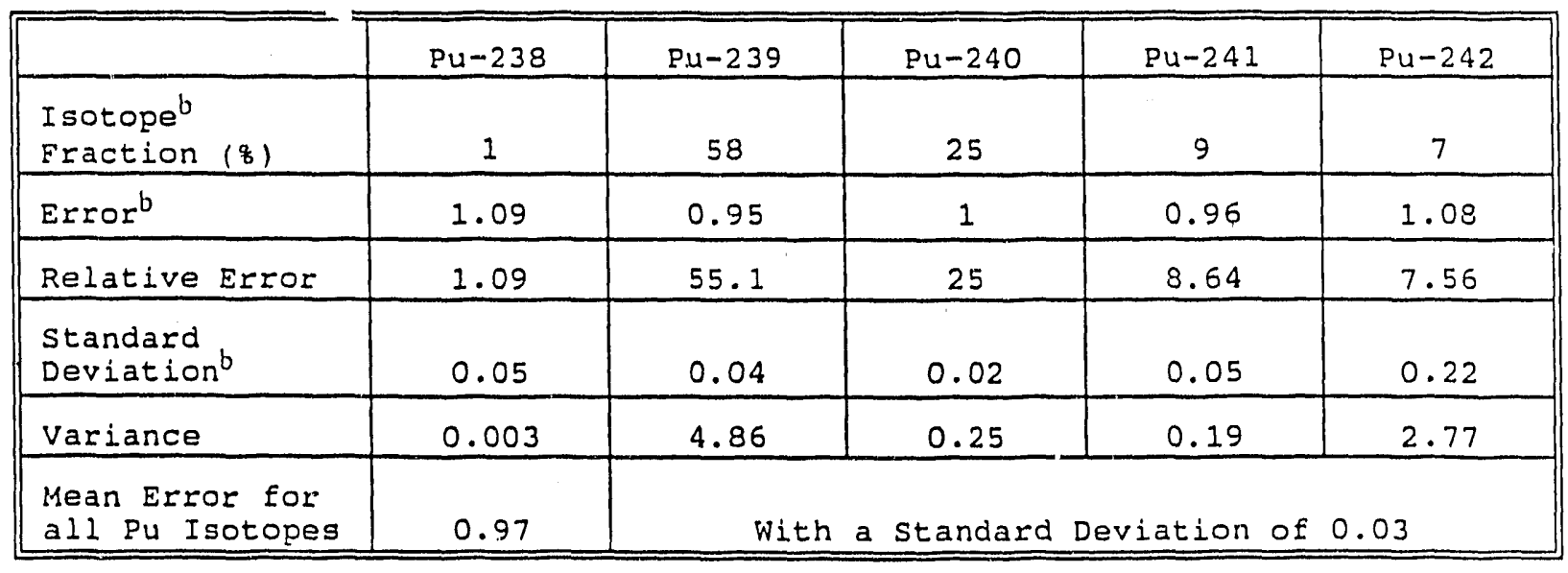

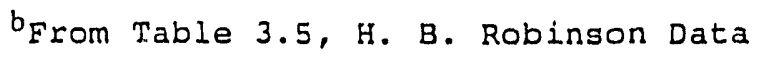


recent paper indicates that discharge burnups are probably within $2 \%$ of actual burnups for fuel with three or more cycles of irradiation. The sensitivity of the calculated actinide content to this low burnup uncertainty should be investigated. The sensitivity studies should also be done for such parameters as enrichment uncertainties, location effects, and material compositions.

Additional studies of reprocessed fuel may also be needed in order to establish a consistent and comprehensive data base for experimentally determined actinide isotopic content. Once such a data base is established, an inter-code comparison study using many different computer codes could be done to determine how individual codes perform relative to each other. Such a study would provide additional information to that obtained by having computer codes run the BNL standard problem. 


\section{References}

1. ASTM Standard E321-79, "Standard Test Method for Atom Percent Fission in Uranium and Plutonium Fuel (Neodymium-148 method), pages 156-167.

2. B.Y. Hubbard, et al, "MICBURN-3/CASMO-3/TABLES-3/SIMULATE-3 Benchmarking of Vermont Yankee Cycles 9 through 13," YAEC-1683, March, 1989.

3. Electric Power Research Institute, "ARMP--Advanced Recycle Methodology Program System Documentation," EPRI-CCM-3 Part 1.1, September, 1977.

4. A.G. Croff, "ORIGEN2: A Versatile Computer Code for Calculating the Nuclide Compositions and Characteristics of Nuclear Materials," Nuclear Technology, V.62, September, 1983.

5. W.R. Cadwell, "PDQ-7 Reference Manual," WAPD-TM-678, Westinghouse Bettis Atomic Power Laboratory, 1967.

6. J.W. Roddy and J.C. Mailen, "Radiological Characteristics of Light-Water Reactor Spent Fuel: A Literature Survey of Experimental Data," ORNL/TM-10105, December, 1987.

7. J.W. Carew, Private Communication.

8. A.S. DiGiovine, et al, "CASMO-3G Validation," YAEC-1363, April, 1988.

9. A. Ahlin, M. Edenius, "CASMO--A Fast Transport Theory Assembly Depletion Code for LWR Analysis," Trans. ANS V.26, 1977, p. 604.

10. M. Edenius, A. Ahlin, and H. Haggblom, "CASMO-2, A Fuel Assembly Burnup Program," Studsvik Energitenik, 1981.

11. B.A. Magurno, et al, "Guidebook of the ENDF/B-V Nuclear Data Files," EPRI NP2510, July, 1982.

12. U. Hesse, "Verification of the OREST(HAMMER-ORIGEN) Depletion Program System using Post-Irradiation Analyses of Fuel Assemblies 168, 170, 171, and 176 from the Obrigheim Reactor," ORNL/TR-88-20, December, 1988.

13. R.J. Nodvik, "Supplementary Report on Evaluation of Mass Spectrometric and Radiochemical Analysis of Yankee Core I," WCAP-6086, August, 1969.

14. M.G. Balfour, et al, "Hot Cell Examination of Zion Fuel Cycles 1 through 4," WCAP10473, April, 1985. 
15. Electric Power Research Institute, "Reactor Core Physics Design and Operating Data for Cycles 1 and 2 of the Zion Unit 2 PWR Power Plant," EPRI NP-1232, December 1979.

16. D.E. Blahnik, U.P. Jenquin, R.J. Guenther, "LWR Spent-Fuel Radiochemical Measurements and Comparison with ORIGEN2 Predictions", Trans. ANS, V.57, p. 44, 1988.

17. N.B. McLeod, "The Accuracy of Fuel Burnup Measurement in Nuclear Reactors," INMM, 1990. 

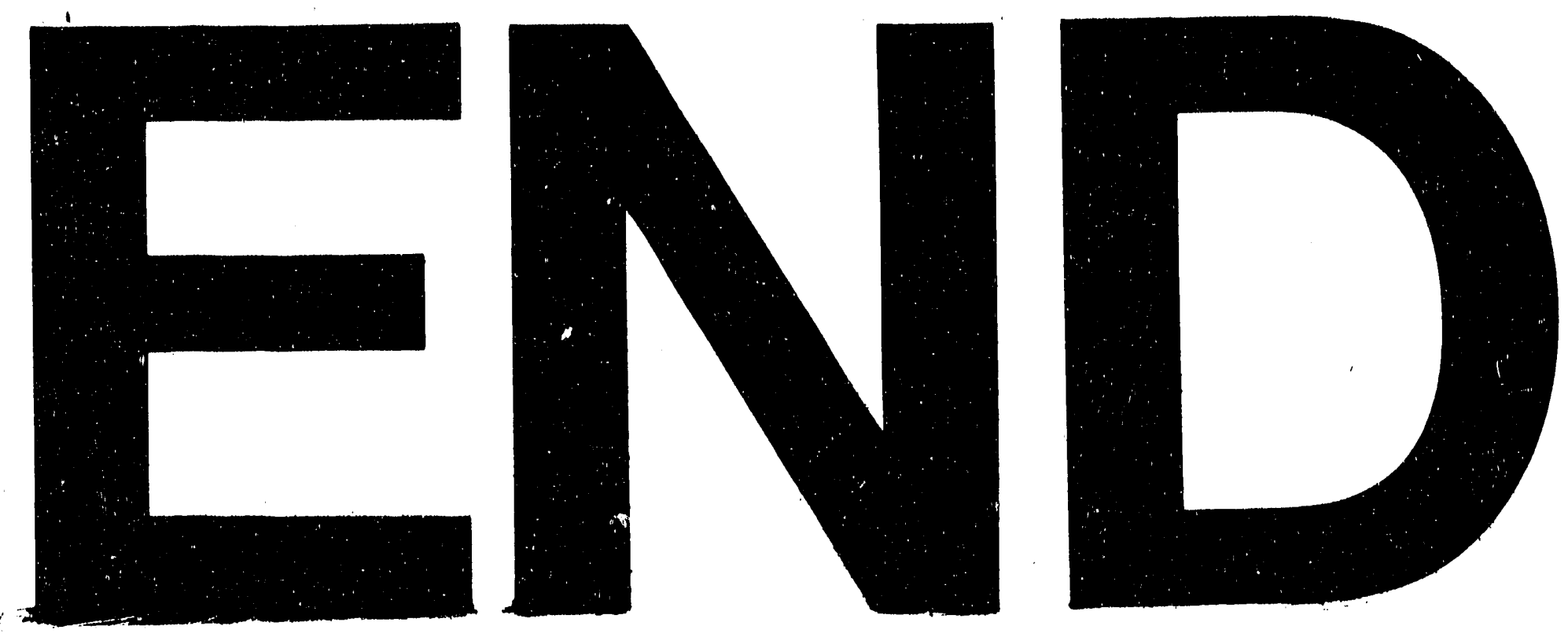

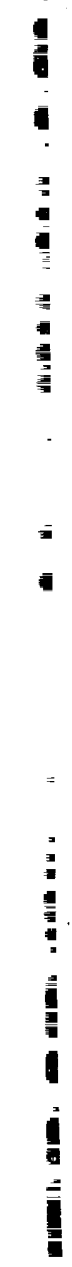
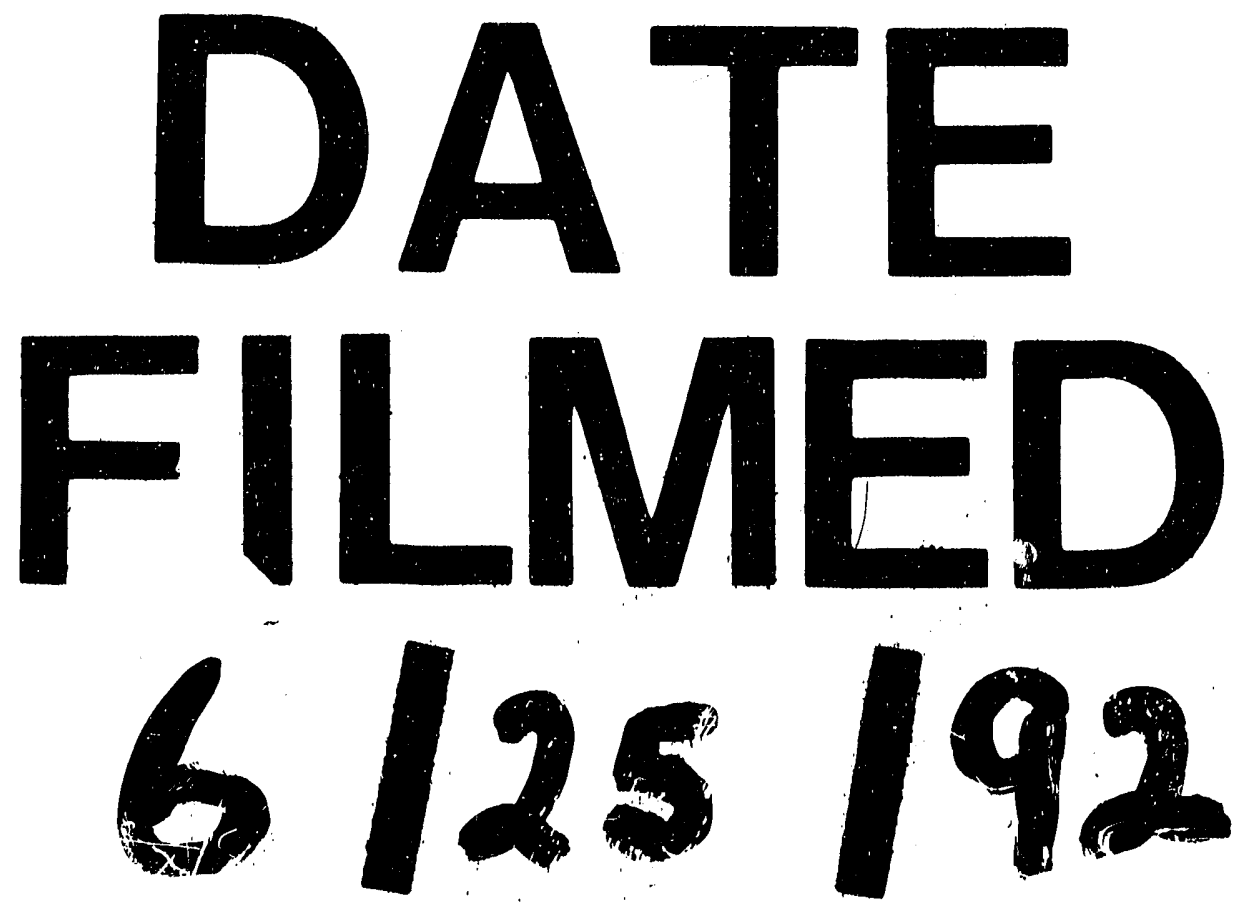
